\title{
Structural Studies on Ceramides as Lithiated Adducts by Low Energy Collisional-Activated Dissociation Tandem Mass Spectrometry with Electrospray Ionization
}

\author{
Fong-Fu Hsu and John Turk \\ Mass Spectrometry Resource, Division of Endocrinology, Diabetes, and Metabolism, Department of Medicine, \\ Washington University School of Medicine, St. Louis, Missouri, USA \\ Mary E. Stewart and Donald T. Downing \\ The Marshall Dermatology Laboratories, Department of Dermatology, The University of Iowa, \\ College of Medicine, Iowa City, Iowa, USA
}

\begin{abstract}
We applied electrospray ionization (ESI) tandem quadrupole mass spectrometry to establish the fragmentation pathways of ceramides under low energy collisional-activated dissociation (CAD) by studying more than thirty compounds in nine subclasses. The product-ion spectra of the $[\mathrm{M}+\mathrm{Li}]^{+}$ions of ceramides contain abundant fragment ions that identify the fatty acyl substituent and the long-chain base (LCB) of the molecules, and thus, the structure of ceramides can be easily determined. Fragment ions specific to each ceramide subclasses are also observed. These feature ions permit differentiation among different ceramide subclasses. The ion series arising from the classical $\mathrm{C}-\mathrm{C}$ bond cleavages that were reported in the fast-atom bombardment (FAB)-high energy tandem mass spectrometry is not observable; however, the product-ion spectra contain multiple fragment ions informative for structural characterization and isomer identification. We also investigated the tandem mass spectra of the fragment ions generated by in-source CAD (pseudo-MS ${ }^{3}$ ) and of the deuterium-labeling molecular species obtained by H/D exchange to support the ion structure assignments and the proposed fragmentation pathways that lead to the ion formation. (J Am Soc Mass Spectrom 2002, 13, 680-695) (C) 2002 American Society for Mass Spectrometry
\end{abstract}

C eramides are $N$-acylated sphingoids (I), consisting of a long-chain aliphatic amino alcohol referred to as long-chain base (LCB), which are covalently linked to a fatty acyl chain via an amide linkage. The major LCB is a sphingosine (sphing-4-enine) (II), and smaller amounts of dihydrosphingosine (sphinganine) (III), phytosphingosine (4-hydroxysphinganine) (IV) also occur. The fatty acids of naturally occurring ceramides range in chain length from $\mathrm{C}_{16}$ to $\mathrm{C}_{26}$, and may contain one or more double bonds/or hydroxyl substituents at C-2. Mammalian stratum corneum, however, contains more classes of ceramides than those made possible by various combinations of the classical building blocks. Pig stratum corneum, for example, contains two ceramides that have unusually long-chain $\omega$-hydroxyacids. One of these $\omega$-hydroxyceramides is solvent-extractable and has an additional fatty acid

Published online May 1, 2002

Address reprint requests to Dr. F.-F Hsu, Department of Internal Medicine, Washington University School of Medicine, 660 S. Euclid, Box 8127, St. Louis, MO 63110, USA. E-mail: fhsu@im.wustl.edu esterified to the $\omega$-hydroxyl group [1], while the other $\omega$-hydroxyceramide is protein-bound [2].

Human stratum corneum ceramides are similar to those in pig [3], except for the existence of a second protein-bound ceramide having a $\omega$-hydroxyacid and a 6-hydroxysphing-4-enine (V) [4]. The identification of the second protein-bound ceramide in human epidermis was recently reported $[5,6]$. These ceramides consist of a 6-hydroxysphing-4-enine bound to an $\omega$-hydroxyacid (esterified to a fatty acid) and to an $\alpha$-hydroxyacid, respectively.

Ceramides are also key compounds in the metabolism of sphingolipids and are emerging as important messengers for various cellular processes including cell cycle arrest, differentiation, apoptosis, senescence, and immune responses [7-13]. Because they have important biological functions, exact analysis of their molecular species and concentrations is crucial for elucidating their function and metabolism. Toward this goal, several methods including thin-layer, high performance liquid chromatography and mass spectrometry have been developed for the identification and quantitation of ceramides [14, 15]. Among them, tandem mass 


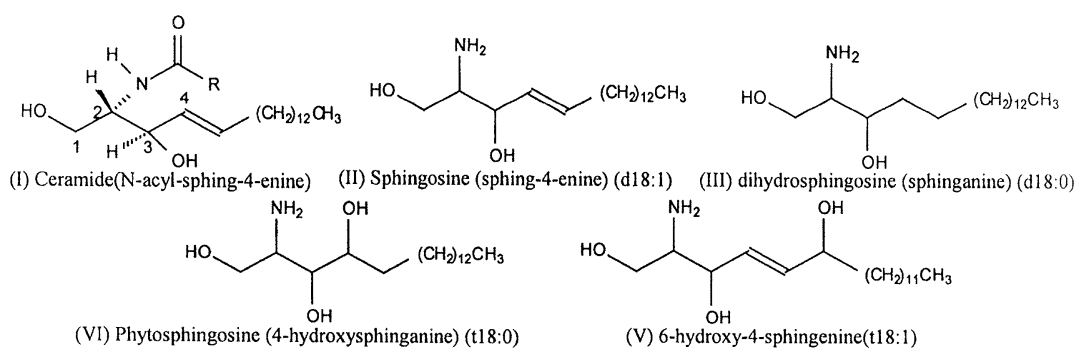

spectrometry with ESI has shown high sensitivity and selectivity for the analysis of ceramides without prior separation and derivatization [14-17].

Structural determination of ceramides as protonated or alkaline-metal adduct ions in the positive-ion mode or as their $[\mathrm{M}-\mathrm{H}]^{-}$ions in the negative-ion mode using tandem mass spectrometry with FAB ionization was previously reported [18-20]. High energy CAD of the $[\mathrm{M}+\mathrm{Li}]^{+}$ions of ceramides provides more structural information than CAD of either the $[\mathrm{M}+\mathrm{H}]^{+}$or $[\mathrm{M}-\mathrm{H}]^{-}$ions [18-20]. Low-energy product-ion spectra of the $[\mathrm{M}+\mathrm{H}]^{+}$ions of ceramides produced by ESI are similar to those obtained by FAB, and only limited structural information is available [17-19]. Herein, we report a study of more than 30 ceramides in nine subclasses by CAD tandem quadrupole mass spectrometry with ESI. The low-energy product-ion spectra of the $[\mathrm{M}+\mathrm{Li}]^{+}$ion of the ceramides contain abundant fragment ions that identify the structures of the fatty acyl substituent and the long-chain base of the molecule, and a more complete structural information than that observed by FAB CAD tandem sector mass spectrometry can be obtained.

\section{Materials and Methods}

\section{Ceramide Standards and Their Abbreviations}

The 6-hydroxy-4-sphingenine-containing ceramides in human skin were isolated as described $[5,6]$. The structures of the ceramides were established by NMR spectroscopy as an acetylated derivative $[5,6]$. The compounds, which were separated as an acetylated derivative by TLC, were deacetylated by adding $1 \mathrm{ml}$ of $1 \mathrm{M} \mathrm{KOH}$ in $95 \%$ methanol-5\% water, heating to $60{ }^{\circ} \mathrm{C}$ for $60 \mathrm{~min}$. After heating, $2 \mathrm{ml}$ of chloroform and $0.6 \mathrm{ml}$ of water (Folch extraction) were added, vortexed for $20 \mathrm{~s}$, and centrifuged at $3000 \times g$ for $5 \mathrm{~min}$. The ceramides were recovered in the chloroform (lower) phase. The chloroform was blown to dryness under $\mathrm{N}_{2}$, reconstituted in chloroform/methanol (1/4) and subjected to ESI/MS analysis.

The designation of ceramide is in the form of dLCB/ FA, with d denoting a dihydroxy long chain base (LCB), namely, a 1,3-dihydroxyl-LCB, of which the 2-aminooctadec-4-ene-1,3-diol (sphing-4-enine) is designated as d18:1. The sphing-4-enine (sphingosine) may be substituted with an additional hydroxy group at C-6 to form a 6-hydroxysphing-4-enine, a trihydroxy long chain base, which is designated as t18:1. The 4-hydroxy sphinganine (phytosphingosine) LCB is designated as t18:0. FA refers to fatty acid, which is designated as nFA for a non-hydroxylated fatty acid, as hFA for an $\alpha$-hydroxy fatty acid, and as $\omega$ FA for an $\omega$-hydroxy fatty acid.

\section{Mass Spectrometry}

ESI/MS analyses were performed on a Finnigan (San Jose, CA) TSQ-7000 triple stage quadrupole mass spectrometer equipped with an electrospray ion source and controlled by Finnigan ICIS software operated on a DEC alpha station. $\mathrm{Na}^{+}$and $\mathrm{K}^{+}$were removed from samples if a high content was observed by ESI analysis. To remove them, samples were dissolved in chloroform and an aliquot $(100 \mathrm{uL})$ of $\mathrm{LiCl}$ solution $(0.6 \%$ aqueous) was added. After vortex, the solution was centrifuged for $5 \mathrm{~min}(3000 \times g)$ and the organic layer was blown to dryness under a stream of nitrogen, and redissolved in chloroform/methanol (1/4), to a final concentration of 5 pmol/uL, which yields abundant $\mathrm{Li}^{+}$adduct ions upon ESI. Otherwise, standard ceramides and ceramide mixtures $(5 \mathrm{pmol} / \mathrm{uL})$ were prepared in chloroform $/$ methanol (1/4), and methanolic $\mathrm{LiCl}(0.1 \mathrm{umol} / \mathrm{uL})$ was added to give a final solution containing $1 \mathrm{nmol} / \mathrm{uL}$ $\mathrm{Li}^{+}$. Samples were infused $(1 \mu \mathrm{L} / \mathrm{min})$ into the ESI source, employing nitrogen as nebulizing gas. The electrospray needle was set at $4.5 \mathrm{kV}$ and the skimmer was at ground potential. The heated capillary temperature was $250{ }^{\circ} \mathrm{C}$. The precursor ion was selected in the first quadrupole (Q1) and collided with Ar (2.3 mtorr) in the rf-only second quadrupole (Q2) using a collision energy of 45-60 eV, and mass analyzed in the third quadrupole (Q3). For CAD tandem mass spectrometry of source-generated fragment ions (source CAD-MS ${ }^{2}$ ), a voltage $(30-60 \mathrm{~V})$ was applied to the ion-transmission octapole to generate the primary fragment ions, which were then selected in the Q1 and collided with $\operatorname{Ar}(2.3$ mtorr) in the Q2, using a collision energy of 25-35 eV. Both the Q1 and Q3 were tuned to unit mass resolution, and the mass spectra were obtained in the profile mode. Typically, a 1 min period of signal averaging was employed for scanned spectra, and 1 to $10 \mathrm{~min}$ was employed for tandem mass spectra. 


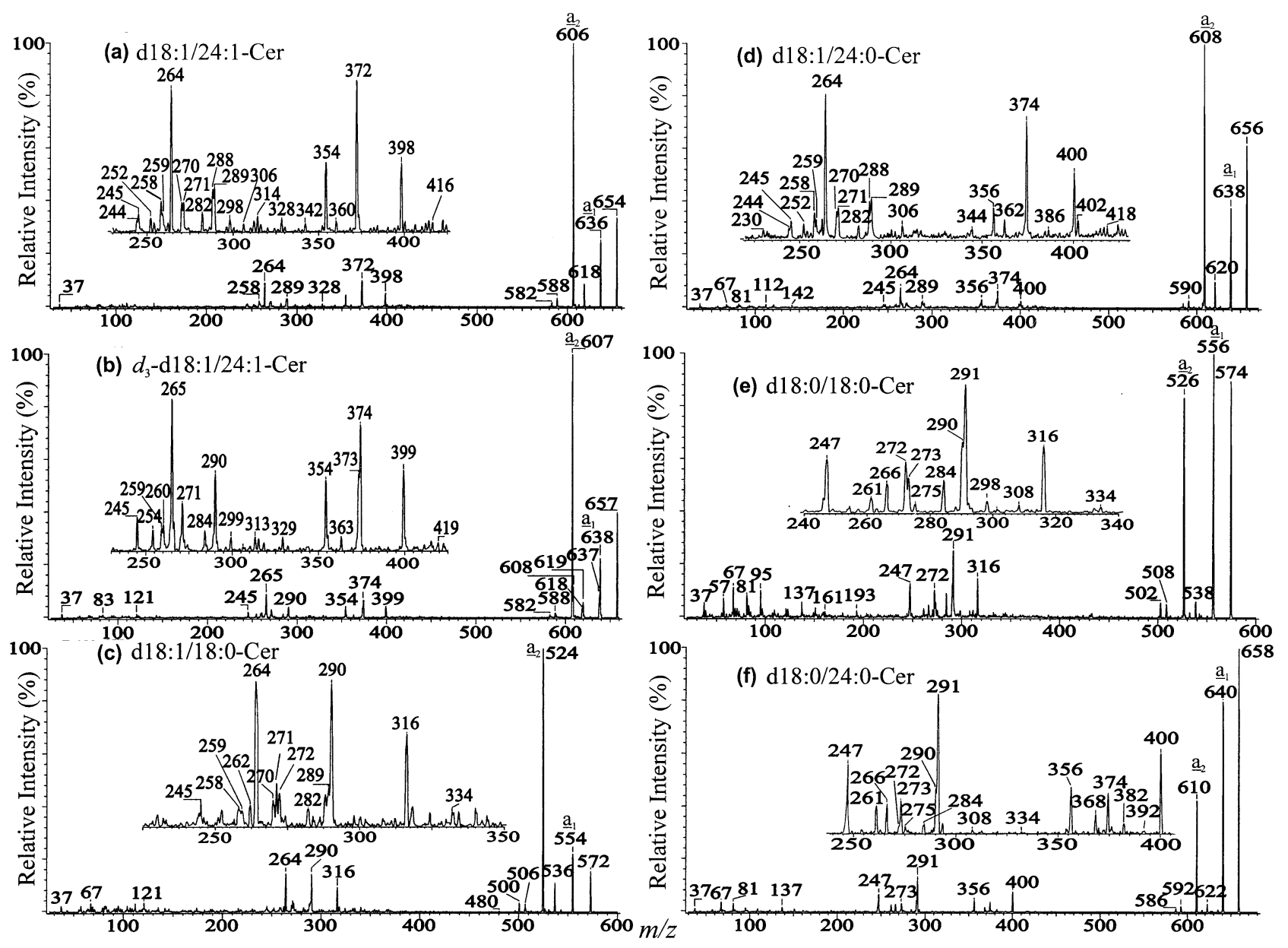

Figure 1. The ESI product-ion spectra of the $[\mathrm{M}+\mathrm{Li}]^{+}$ions of (a) $\mathrm{d} 18: 1 / 24: 1-\mathrm{Cer}$ at $\mathrm{m} / \mathrm{z}$ 654, (b) $\mathrm{d}_{3}$-d18:1/24:1-Cer at $\mathrm{m} / \mathrm{z}$ 657, (c) $\mathrm{d} 18: 1 / 18: 0$-Cer at $\mathrm{m} / \mathrm{z}$ 572, (d) $\mathrm{d} 18: 1 / 24: 0-$ Cer at $\mathrm{m} / \mathrm{z}$ 656, (e) d18:0/18:0-Cer at $m / z$ 574, and (f) d18:0/24:0-Cer at $m / z 658$.

\section{Results and Discussion}

In the presence of alkaline metal ions, ceramides yield abundant adduct ions $\left([\mathrm{M}+\mathrm{Alk}]^{+}\right.$, where Alk $=\mathrm{Li}, \mathrm{Na}$, K) upon ESI. However, only the lithiated adduct ion $\left([\mathrm{M}+\mathrm{Li}]^{+}\right)$yields fragment ions that are informative for structural determination, similar to those obtained by high-energy tandem mass spectrometry [18-20]. The unique features of the $\left[\mathrm{M}+\mathrm{Li}^{+}\right.$adduct ion applicable in the structural characterization using CAD tandem mass spectrometry were previously addressed [19, 21, 22]. The low-energy CAD tandem mass spectra of the $[\mathrm{M}+\mathrm{Li}]^{+}$ions of ceramides also yield more structurally informative ions than those obtained from the $[\mathrm{M}+$ $\mathrm{H}]^{+}$ions [17] or from the $[\mathrm{M}+\mathrm{Cl}]^{-}$ions in negative-ion mode [23]. The designation of the fragment ions previously used in the high energy CAD study [18-20] is not adopted because of the complexities of the ions observed.

\section{$N$-Acylsphingosines}

When subjected to CAD, the $\left[\mathrm{M}+\mathrm{Li}^{+}\right.$ion of $\mathrm{N}-$ tetradodecenylsphingosine (d18:1/24:1-Cer) at $\mathrm{m} / \mathrm{z} 654$ yields a prominent ion at $m / z 636$ by loss of $\mathrm{H}_{2} \mathrm{O}$ (Figure 1a). This is followed by further loss of $\mathrm{H}_{2} \mathrm{O}$ or $\mathrm{HCHO}$ to give rise to ions at $\mathrm{m} / \mathrm{z} 618$ or 606 , respectively. The formation of the $\mathrm{m} / \mathrm{z} 636$ ion by a water loss from $\mathrm{m} / \mathrm{z}$ 654 may involve different mechanisms. This is revealed by the product-ion spectrum of the $[\mathrm{M}+\mathrm{Li}]^{+}$ion of $\mathrm{d}_{3}$-d18:1/24:1-Cer prepared by H-D exchange (Figure $1 b)$. The spectrum contains the analogous ions at $\mathrm{m} / \mathrm{z}$ 637 (loss of $\mathrm{D}_{2} \mathrm{O}$ ) and 638 (loss of $\mathrm{DHO}$ ), indicating that the water loss can involve two or one exchangeable hydrogen. The $\mathrm{m} / \mathrm{z} 636$ ion successively yields a prominent ion at $m / z 606\left(\underline{a}_{2}\right)$ by loss of HCHO, or decomposes to a lithiated amide at $m / z 372\left(\underline{d}_{1 a}\right.$, Scheme $\left.\mathbf{1 b}\right)$. The $\mathrm{HCHO}$ loss is consistent with the presence of the $\mathrm{m} / \mathrm{z} 37$ ion, which is a $\left[\mathrm{HCHO}+\mathrm{Li}^{+}\right.$ion [24]. This process is confirmed by the product-ion spectrum of the $\mathrm{m} / \mathrm{z} 636$ ion (Figure $2 \mathrm{a}$ ), generated by source CAD of d18:1/24:1-Cer at $m / z$ 654. The $m / z 372$ ion can also arise from direct cleavage of the $\mathrm{C} 2-\mathrm{N}$ bond of the LCB (Scheme $\mathbf{1 b}$ ), as is revealed by the observation of the analogous ions of $m / z 373$ and $374\left(\underline{d}_{1 a}\right)$ in the production spectrum of the lithiated $\mathrm{d}_{3}$-d18:1/24:1-Cer (Figure $1 b)$. The variation in the mass shifts of these two ions 


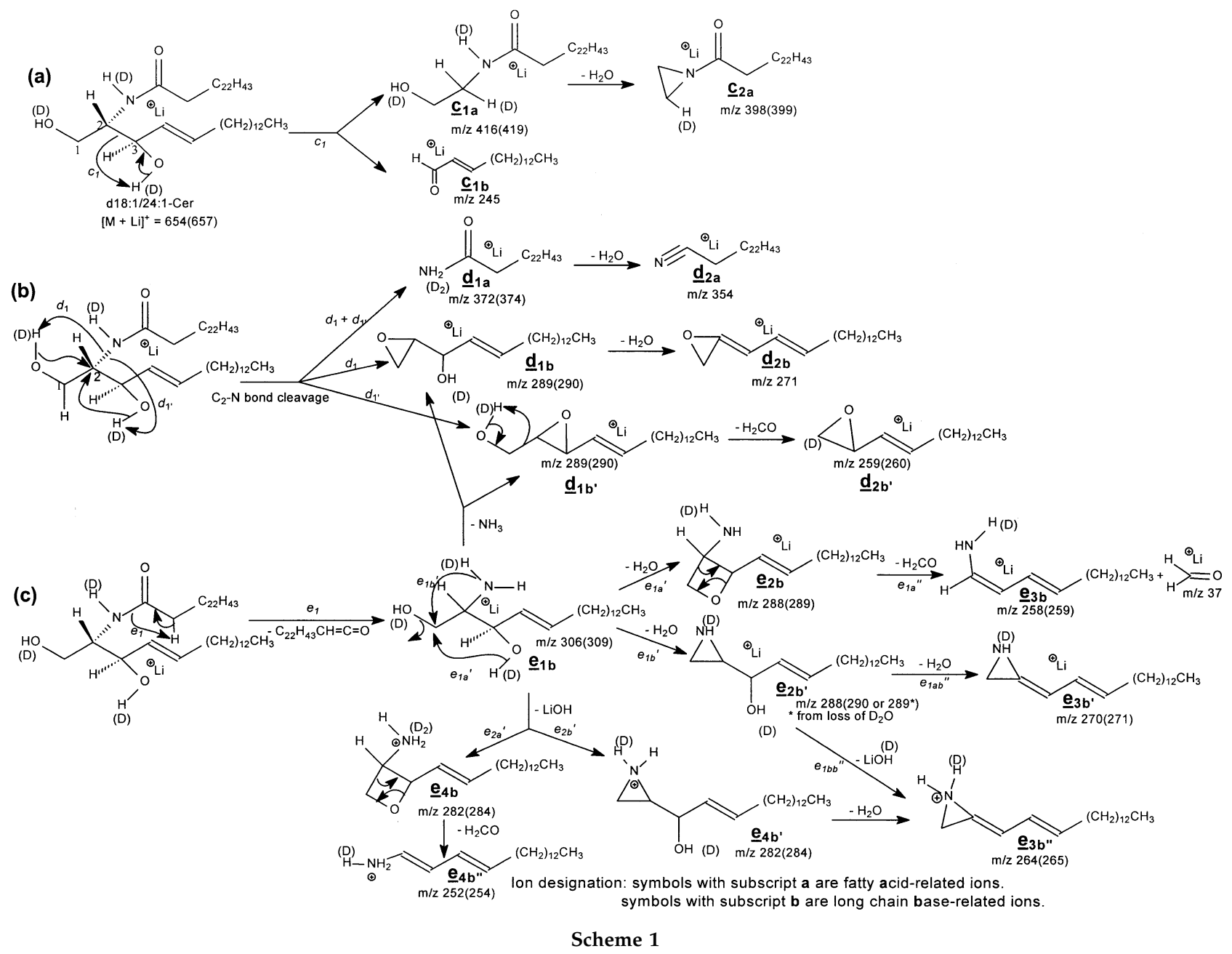

arises from the exchangeable hydrogens. This result indicates that the two ions may derive from different pathways, or by H/D scrambling prior to fragmentation. The multiple pathways for formation of the $\mathrm{m} / \mathrm{z}$ 636 ion are also supported by the product-ion spectra of the two isomeric ions of $\mathrm{m} / \mathrm{z} 637$ (Figure $2 \mathrm{~b}$ ) and 638 (Figure 2c), generated from source CAD of $\mathrm{d}_{3}-\mathrm{d} 18: 1 / 24$ : 1-Cer. The two spectra are readily distinguishable, consistent with the assignment that they are of isomers. The latter spectrum also contains more fragment ions than that of the former, indicating that the ions informative for the structural elucidation arise from further fragmentations of the $\mathrm{m} / \mathrm{z} 638$ ion rather than the $\mathrm{m} / \mathrm{z}$ 637 ion. The summed product-ion spectrum of the two is similar to that arising from the $m / z 636$ ion (Figure 2a), generated by in-source CAD of the $[\mathrm{M}+\mathrm{Li}]^{+}$ion of $\mathrm{d} 18: 1 / 24: 1-C e r$, and the abundance ratio of the $\mathrm{m} / \mathrm{z}$ 638/637 ions also increases as the collision energy increases (data not shown). These results are consistent with the notion that the $\mathrm{m} / \mathrm{z} 636$ ion indeed arises via multiple pathways, and also consistent with the fragmentation pathways previously proposed for glycosphingolipids [24].

It appears that several cleavages involving the LCB chain have occurred. Although some of the ions arising from these cleavages are of low abundance and thus are of less diagnostic value, they appear to be precursors of many prominent ions that are informative for structural characterization. For example, the cleavage of the $\mathrm{C} 2-\mathrm{C} 3$ bond of the LCB (Scheme 1a) results in a lithiated aldehyde ion at $\mathrm{m} / \mathrm{z} 245\left(\left[\mathrm{CH}_{3}\left(\mathrm{CH}_{2}\right)_{12} \mathrm{CH}=\mathrm{CHCHO}+\right.\right.$ $\left.\mathrm{Li}]^{+}\right)\left(\underline{c}_{1 b}\right)$. This cleavage also results in a low-abundance ion of $m / z 416\left(\underline{c}_{1 \mathrm{a}}\right)$, which leads to a prominent ion at $m / z 398\left(\underline{c}_{2 a}\right)$ by loss of $\mathrm{H}_{2} \mathrm{O}$. The direct cleavage of the C2-N bond (Scheme 1b) give rise to the $m / z 372$ ion $\left(\underline{\mathrm{d}}_{1 \mathrm{a}}\right)$, along with $m / z 289$, possibly a lithiated oxirane $\left(\underline{\mathrm{d}}_{1 \mathrm{~b}}\right)$ or a lithiated epoxide ion $\left(\underline{\mathrm{d}}_{1 \mathrm{~b}}\right)$. The configurations for the $\mathrm{m} / \mathrm{z} 289$ ion are deduced by the fact that both a $m / z 271\left(\underline{\mathrm{d}}_{2 \mathrm{~b}}\right)$ and a $m / z 259\left(\underline{\mathrm{d}}_{2 \mathrm{~b}}\right)$ ion were also observed in the spectrum. The former ion may arise from a $\mathrm{H}_{2} \mathrm{O}$ loss from an oxirane intermediate of the $\mathrm{m} / \mathrm{z} 289$ ion $\left(\underline{d}_{1 b}\right)$, which is primarily formed by the participation of the 1-hydroxy hydrogen for the $\mathrm{C} 2-\mathrm{N}$ bond cleavage (route $d_{1}$ ), whereas the $m / z 259\left(\underline{\mathrm{d}}_{2 \mathrm{~b}}\right)$ ion is formed by loss of $\mathrm{HCHO}$ from a lithiated epoxide intermediate of $m / z 289\left(\underline{d}_{1 b}\right)$, which arises from the same cleavage involving the 3-hydroxy hydrogen (route $d_{1}$ ) of the 


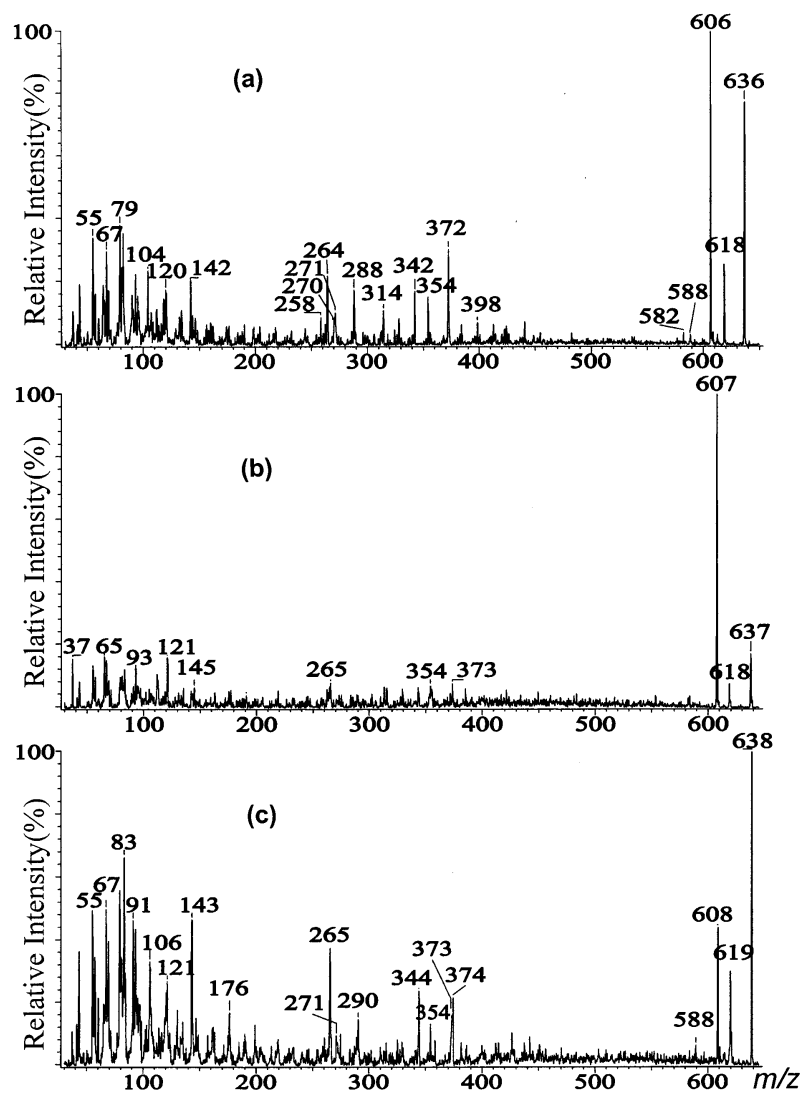

Figure 2. The product-ion spectra (a) of the $m / z 636$ ion, generated from source CAD of the $[\mathrm{M}+\mathrm{Li}]^{+}$ions of d18:1/24:1-Cer, (b) of the $\mathrm{m} / \mathrm{z} 637$ and (c) of the $\mathrm{m} / \mathrm{z} 638$ ion, generated from source CAD of $\mathrm{d}_{3}$-d18:1/24:1-Cer.
LCB. The $m / z 372$ ion may also undergo a $\mathrm{H}_{2} \mathrm{O}$ loss to a $m / z 354$ ion $\left(\underline{d}_{2 a}\right)$.

The elimination of the fatty acyl group as a ketene (loss of $\mathrm{C}_{22} \mathrm{H}_{43} \mathrm{CH}=\mathrm{C}=\mathrm{O}$ ) (Scheme 1c) from the $\mathrm{m} / \mathrm{z} 654$ ion results in a low-abundance ion of $m / z 306\left(\underline{e}_{1 b}\right)$, which becomes the most prominent in the product-ion spectra of the $N$ - $\alpha$-hydroxylsphingosines (discussed later). The $\mathrm{m} / \mathrm{z} 306$ ion is a lithiated sphingosine, which appears to be the precursor ion leading to the $\mathrm{m} / \mathrm{z} 288$ or 289 ion by a $\mathrm{H}_{2} \mathrm{O}$ or $\mathrm{NH}_{3}$ loss, respectively. The $\mathrm{m} / \mathrm{z} 306$ ion may also yield the protonated ion species of $\mathrm{m} / \mathrm{z} 282$ $\left(\underline{\mathrm{e}}_{4 \mathrm{~b}}+\underline{\mathrm{e}}_{4 \mathrm{~b}}\right)$ via loss of $\mathrm{LiOH}$. The $\mathrm{H}_{2} \mathrm{O}$ loss from $\mathrm{m} / \mathrm{z} 306$ may involve two pathways leading to a lithiated oxetane $\left(\underline{e}_{2 b}\right)$ or a lithiated aziridine $\left(\underline{e}_{2 b}\right)$ ion of $m / z 288$. The oxetane intermediate of $\mathrm{m} / \mathrm{z} 288\left(\underline{\mathrm{e}}_{2 \mathrm{~b}}\right)$ arises from the water loss that involves the 3-hydroxyl hydrogen of the LCB (route $e_{1 a}$ ) and further dissociates to a conjugated diene at $m / z 258\left(\underline{e}_{3 \mathrm{~b}}\right)$ or to a lithiated $\mathrm{HCHO}$ ion at $\mathrm{m} / \mathrm{z}$ 37 , whereas the aziridine intermediate of $\mathrm{m} / \mathrm{z} 288$ ion $\left(\underline{e}_{2 b}\right)$ arises from a ring closure by the water loss involving the amide hydrogen (route $e_{1 b}$ ). This is followed by another water or $\mathrm{LiOH}$ loss to yield a $\mathrm{m} / \mathrm{z} 270$ $\left(\underline{\mathrm{e}}_{3 \mathrm{~b}}\right)$ (route $e_{1 a b^{\prime \prime}}$ ) or 264 ion $\left(\underline{\mathrm{e}}_{3 \mathrm{~b}^{\prime \prime}}\right)$ (route $\left.e_{16 b^{\prime \prime}}\right)$. The similar fragmentation pathways can be reasoned for the formation of the protonated oxetane $\left(\underline{\mathrm{e}}_{4 \mathrm{~b}}\right)$ (route $e_{2 a^{\prime}}$ ) or aziridine $\left(\mathrm{e}_{4 \mathrm{~b}}\right.$ ) (route $e_{2 b^{\prime}}$ ) ion of the $\mathrm{m} / \mathrm{z} 282$ ion arising from a $\mathrm{LiOH}$ loss from the $\mathrm{m} / \mathrm{z} 306$ ion. These pathways are also consistent with the observation of the prominent ions of $m / z 252\left(\underline{\mathbf{e}}_{4 \mathrm{~b}^{\prime \prime}}\right)$ and $264\left(\underline{\mathrm{e}}_{3 \mathrm{~b}^{\prime \prime}}\right)$ arising from $\mathrm{m} / \mathrm{z}$ 282 by loss of $\mathrm{HCHO}$ and $\mathrm{H}_{2} \mathrm{O}$, respectively. The above fragmentation pathways are confirmed by the production spectra of the $\mathrm{m} / \mathrm{z} 306$ (Figure 3a) and $\mathrm{m} / \mathrm{z} 288$ (Figure $3 b$ ) ions, generated by source $\mathrm{CAD}$ of the

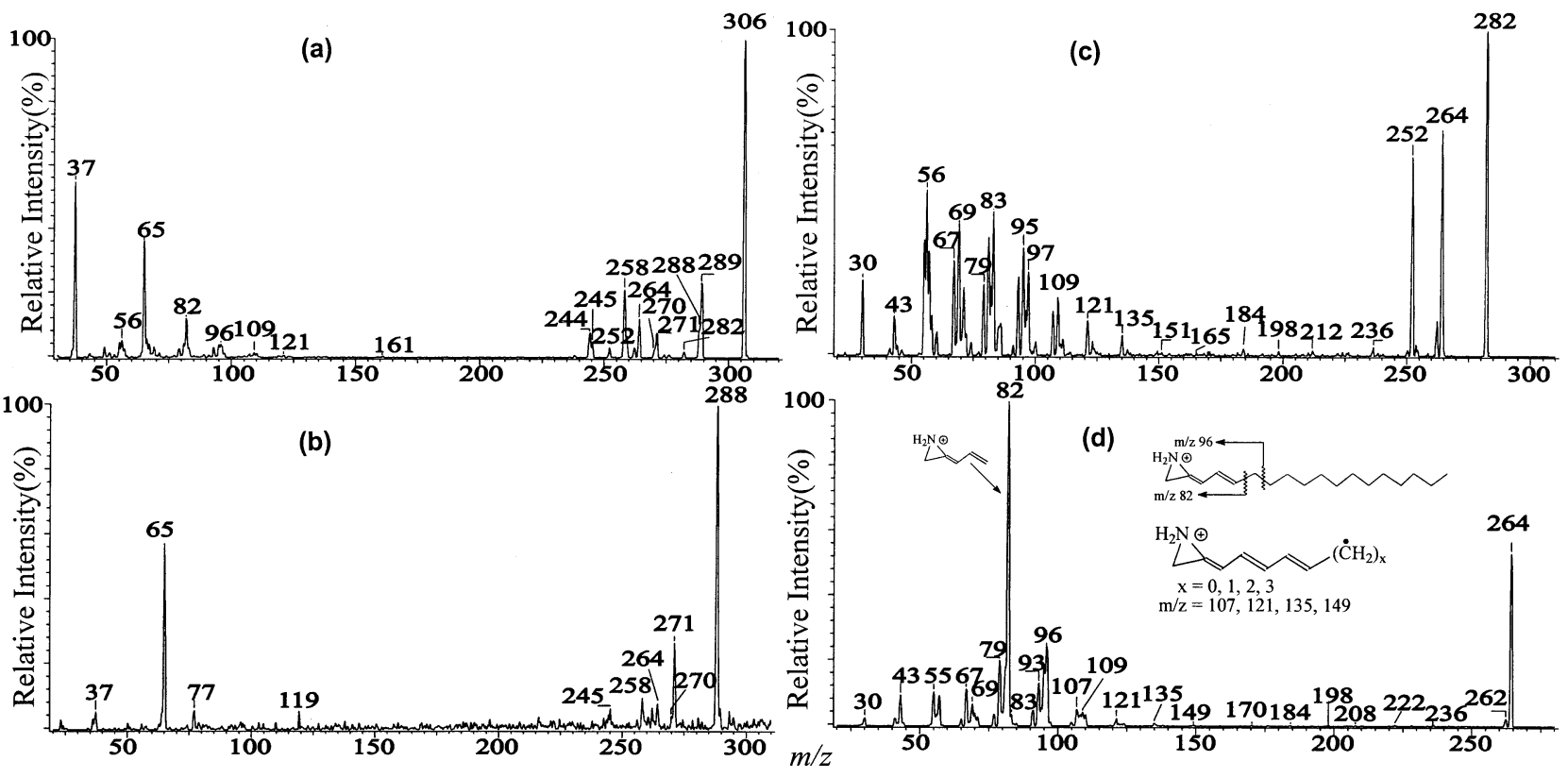

Figure 3. The product-ion spectra of (a) the $m / z 306$ ion, (b) the $m / z 288$ ion, (c) the $m / z 282$ ion, and (d) the $\mathrm{m} / z 264$ ion. The ions at $\mathrm{m} / \mathrm{z} 306$ and 288 were generated from source CAD of the [M $+\mathrm{Li}]^{+}$ ions of d18:1/24:1-Cer at $\mathrm{m} / \mathrm{z} 654$. The $\mathrm{m} / \mathrm{z} 282$ and 264 ions were generated from source CAD of the $[\mathrm{M}+\mathrm{H}]^{+}$ion of $\mathrm{d} 18: 1 / 24: 1-\mathrm{Cer}$ at $m / z 648$. 
Table 1. Major fragment ions observed for various ceramide standards

\begin{tabular}{|c|c|c|c|c|c|c|c|c|c|c|c|c|c|c|c|c|c|c|}
\hline \multicolumn{3}{|c|}{ Ceramide species } & \multicolumn{16}{|c|}{ Fragment ions from CAD of $[\mathrm{M}+\mathrm{Li}]^{+}$} \\
\hline \multirow[b]{2}{*}[\mathrm{M}+\mathrm{Li}]{$^{+}$} & \multirow[b]{2}{*}{ Fatty acid } & \multirow[b]{2}{*}{ LCB } & \multicolumn{3}{|c|}{ common ions $(\mathrm{m} / \mathrm{z})$} & \multicolumn{7}{|c|}{ FA ions $(m / z)$} & \multicolumn{6}{|c|}{ LCB ions $(m / z)$} \\
\hline & & & $\underline{a}_{1}$ & $\underline{a}_{2}\left(\underline{a}_{1}-30\right)$ & $\underline{\mathrm{a}}_{1}-18$ & $\underline{\mathrm{C}}_{2 \mathrm{a}}$ & $\underline{\mathrm{C}}_{3 \mathrm{a}^{\prime}}{ }^{\mathrm{d}}$ & $\underline{\mathrm{b}}_{1 \mathrm{a}}{ }^{\mathrm{d}}$ & $\underline{\mathrm{b}}_{2 \mathrm{a}}{ }^{\mathrm{d}}$ & $g_{3 a}{ }^{d}$ & $\underline{\mathrm{d}}_{1 \mathrm{a}}$ & $\underline{d}_{2 a}{ }^{d}$ & $\underline{d}_{3 b}$ & $\underline{\mathrm{e}}_{1 \mathrm{~b}}$ & $\begin{array}{c}\underline{\mathrm{e}}_{2 \mathrm{~b}}+ \\
\underline{\mathrm{e}}_{2 \mathrm{~b}^{\prime}} \\
\end{array}$ & $\underline{\mathrm{e}}_{3 \mathrm{~b}^{\prime}}$ & $\underline{\mathrm{e}}_{3 \mathrm{~b}^{\prime \prime}}$ & $\underline{f}_{3 b^{\prime}}$ \\
\hline 656 & $24: 0$ & d18:1 & 638 & 608 & 620 & $400^{d}$ & & & & & $374^{d}$ & 356 & & & $288^{d}$ & $270^{d}$ & $264^{d}$ & \\
\hline 654 & $24: 1$ & d18:1 & 636 & 606 & 618 & $398^{\mathrm{d}}$ & & & & & $372^{d}$ & 354 & & & $288^{d}$ & $270^{d}$ & $264^{d}$ & \\
\hline 657 & $24: 1$ & $d_{3}-d 18: 1$ & 638,637 & 607 & 618,619 & $399^{d}$ & & & & & $374,375^{d}$ & 354 & & & $290^{d}$ & $271^{d}$ & $265^{d}$ & \\
\hline 432 & 8:0 & d18:1 & 414 & 384 & 396 & $176^{\mathrm{d}}$ & & & & & $150^{d}$ & 132 & & & $288^{d}$ & $270^{d}$ & $264^{d}$ & \\
\hline 544 & 16:0 & d18:1 & 526 & 496 & 508 & $288^{d}$ & & & & & $262^{\mathrm{d}}$ & 244 & & & $288^{d}$ & $270^{d}$ & $264^{d}$ & \\
\hline 572 & $18: 0$ & d18:1 & 554 & 524 & 536 & $316^{d}$ & & & & & $290^{d}$ & 272 & & & $288^{d}$ & $270^{d}$ & $264^{d}$ & \\
\hline 658 & $24: 0$ & d18:0 & 640 & 610 & 622 & $400^{d}$ & & & & & $374^{\mathrm{d}}$ & 356 & 275 & 308 & $290^{d}$ & 272 & $266^{d}$ & \\
\hline 661 & $24: 0$ & $d_{3}-d 18: 0$ & 641,642 & 611 & 622,623 & $401^{d}$ & & & & & $375,376^{d}$ & 356 & 276 & 311 & $291^{d}$ & 273 & $267^{d}$ & \\
\hline 574 & $18: 0$ & d18:0 & 556 & 526 & 538 & $316^{d}$ & & & & & $290^{d}$ & 272 & 275 & 308 & $290^{d}$ & 272 & $266^{d}$ & \\
\hline 672 & h24:0 & d18:1 & 654 & 624 & 636 & 416 & 345 & & & & 390 & & 273 & 306 & $288^{d}$ & 270 & 264 & $298^{d}$ \\
\hline 676 & $\mathrm{~d}_{1}-\mathrm{h} 24: 0$ & $d_{3}-d 18: 1$ & 656,657 & 626 & 639,638 & 418 & 345 & & & & 392,393 & & 274 & 310 & $290^{d}$ & 271 & 266 & $299^{d}$ \\
\hline 670 & h24:1 & d18:1 & 652 & 622 & 634 & 414 & 343 & & & & 388 & & 273 & $306^{d}$ & $288^{d}$ & 270 & 264 & $298^{d}$ \\
\hline 532 & h16:0 & d16:1 & 514 & 484 & 496 & 304 & 233 & & & & 278 & & 245 & $278^{d}$ & $260^{d}$ & 242 & 236 & $270^{d}$ \\
\hline 546 & h16:0 & d17:1 & 528 & 498 & 510 & 304 & 233 & & & & 278 & & 259 & $292^{d}$ & $274^{d}$ & 256 & 250 & $284^{d}$ \\
\hline 560 & h16:0 & d18:1 & 542 & 512 & 524 & 304 & 233 & & & & 278 & & 273 & $306^{d}$ & $288^{d}$ & 270 & 264 & $298^{d}$ \\
\hline 562 & h16:0 & d18:0 & 544 & 514 & 526 & 304 & 233 & & & & 278 & & $275^{d}$ & $308^{d}$ & $290^{d}$ & 272 & & 300 \\
\hline 590 & h18:0 & d18:0 & 572 & 542 & 554 & 332 & 261 & & & & 306 & & $275^{d}$ & $308^{d}$ & $290^{d}$ & 272 & & 300 \\
\hline 548 & h16:0 & d17:0 & 530 & 500 & 512 & 304 & 233 & & & & 278 & & $261^{d}$ & $294^{d}$ & $276^{d}$ & 258 & & 286 \\
\hline 756 & $\omega 30: 0$ & d18:1 & 738 & 708 & 720 & $500^{d}$ & & & & & $474^{d}$ & 456 & & & 288 & 270 & 264 & \\
\hline \multirow[t]{2}{*}{784} & $\omega 30: 0$ & $\mathrm{~d} 20: 1$ & 766 & 736 & 748 & $500^{d}$ & & & & & $474^{d}$ & 456 & & & 316 & 298 & 292 & \\
\hline & $\omega 32: 0$ & d18:1 & 766 & 736 & 748 & $500^{d}$ & & & & & $502^{d}$ & 484 & & & 288 & 270 & 264 & \\
\hline 578 & h16:0 & $\mathrm{t} 18: 0$ & 560 & 530 & 542 & 304 & 233 & & & & 278 & & $291^{d}$ & $324^{d}$ & $306^{d}$ & 288 & & 316 \\
\hline 564 & h16:0 & $\mathrm{t} 17: 0$ & 546 & 516 & 528 & 304 & 233 & & & & 278 & & $277^{d}$ & $310^{d}$ & $292^{d}$ & 274 & & 302 \\
\hline \multirow[t]{2}{*}{800} & $\omega 30: 0$ & $\mathrm{t} 20: 1$ & 782 & 752 & 764 & $500^{d}$ & & & & 526 & $474^{d}$ & 456 & 317 & & 332 & $314^{d}$ & 308 & \\
\hline & $\omega 32: 0$ & t18:1 & 782 & 752 & 764 & $528^{d}$ & & & & 554 & $502^{d}$ & 484 & 289 & & 304 & ${ }^{*} 286^{d}$ & $* * 280$ & \\
\hline 772 & $\omega 30: 0$ & t18:1 & 754 & 724 & 736 & $500^{d}$ & & & & 526 & $474^{d}$ & 456 & 289 & & 304 & ${ }^{*} 286^{d}$ & $* * 280$ & \\
\hline 744 & $\omega 28: 0$ & $\mathrm{t} 18: 1$ & 726 & 696 & 708 & $472^{d}$ & & & & 498 & $446^{d}$ & 428 & 289 & & 304 & $* 286^{d}$ & $* * 280$ & \\
\hline \multirow[t]{3}{*}{674} & $24: 0$ & $\mathrm{t} 18: 0$ & 656 & 626 & 638 & $400^{d}$ & & 428 & 416 & & $374^{d}$ & 356 & 291 & & 306 & $288^{d}$ & & \\
\hline & 25:0 & $\mathrm{t} 17: 0$ & 656 & 626 & 638 & 414 & & 442 & 430 & & $388^{d}$ & 370 & 277 & & 292 & 274 & & \\
\hline & $26: 0$ & $\mathrm{t} 16: 0$ & 656 & 626 & 638 & 428 & & 456 & 444 & & $402^{d}$ & 384 & 263 & & 278 & 260 & & \\
\hline 660 & $24: 0$ & $\mathrm{t} 17: 0$ & 642 & 612 & 624 & 400 & & 428 & 416 & & $374^{d}$ & 356 & 277 & & 292 & 274 & & \\
\hline 702 & $26: 0$ & $\mathrm{t} 18: 0$ & 684 & 654 & 666 & 428 & & 456 & 444 & & $402^{d}$ & 384 & 291 & & 306 & 288 & & \\
\hline 688 & h24:0 & $\mathrm{t} 18: 1$ & 670 & 640 & 652 & 416 & 345 & & & & 390 & & $289^{d}$ & $322^{d}$ & $304^{d}$ & $286^{d}$ & & 314 \\
\hline 716 & h26:0 & t18:1 & 698 & 668 & 680 & 444 & 373 & & & & 418 & & $289^{d}$ & $322^{d}$ & $304^{d}$ & $286^{d}$ & & 314 \\
\hline
\end{tabular}



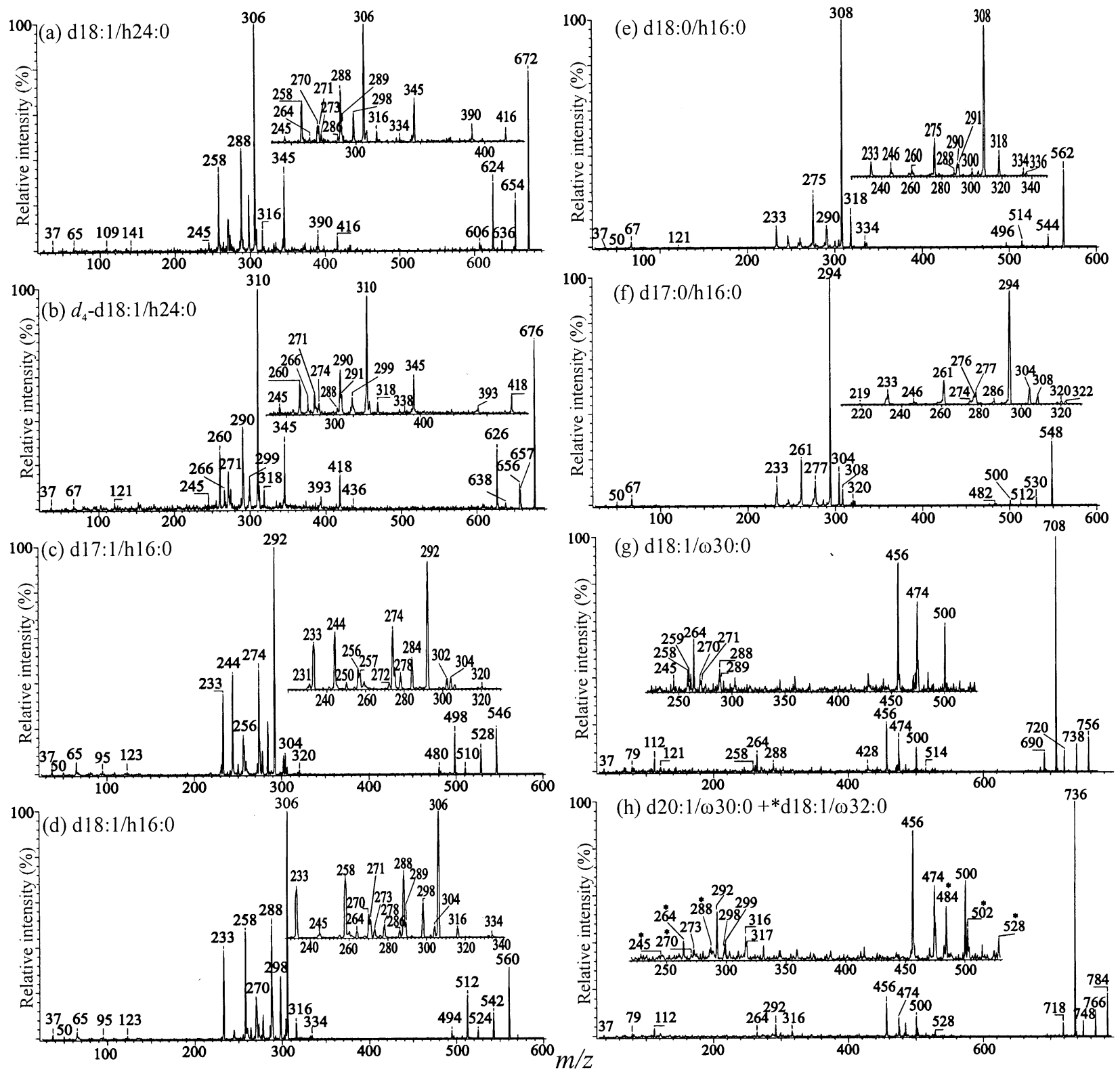

Figure 4. The product-ion spectra of the $[\mathrm{M}+\mathrm{Li}]^{+}$ion of (a) d18:1/h24:0-Cer at $\mathrm{m} / \mathrm{z}$ 672, (b) $\mathrm{d}_{4}$-d18:1/h24:0-Cer at $\mathrm{m} / z$ 676, (c) d17:1/h16:0-Cer at $\mathrm{m} / \mathrm{z}$ 546, (d) d18:1/h16:0-Cer at $\mathrm{m} / \mathrm{z}$ 560, (e) d18:0/h16:0-Cer at $m / z$ 562, (f) d17:0/h16:0-Cer at $m / z$ 548, (g) d18:1/ $\omega 30: 0-C e r$ at $m / z$ 756, and of (h) $\left(\mathrm{d} 20: 1 / \omega 30: 0+{ }^{*} \mathrm{~d} 18: 1 / \omega 32: 0\right)-C e r$ at $\mathrm{m} / z$ 784. The fragmentations of the ceramides are facilitated by the presence of the $\alpha$-hydroxyl group of the fatty acyl chain, regardless of the LCB (panels a-f), and not affected by the $\omega$-hydroxyl group (panels $\mathbf{g}$, $\mathbf{h}$ ). The analogous ions arising from the second isomer in panel $\mathrm{H}$ are marked with an asterisk.

lithiated 18:1/24:1-Cer at $\mathrm{m} / \mathrm{z} 654$, and of $\mathrm{m} / \mathrm{z} 282$ ion (Figure 3c), generated by source CAD of the protonated 18:1/24:1-Cer at $m / z 648$.

The $m / z 264\left(\underline{\mathbf{e}}_{3 \mathrm{~b}^{\prime \prime}}\right)$ is the most prominent ion observed for the $[\mathrm{M}+\mathrm{H}]^{+}$ions of d18:1/nFA-Cer after CAD [17, 21]. We speculate that the $\mathrm{m} / \mathrm{z} 264$ is a conjugated aziridine ion $\left(\mathrm{e}_{3 \mathrm{~b}}\right.$ ", Scheme $\left.1 \mathrm{c}\right)$. This is based on the findings that the product-ion spectrum of the $\mathrm{m} / \mathrm{z} 264$ ion (Figure 3d) contains a prominent ion at $\mathrm{m} / \mathrm{z} 82$, possibly corresponding to a stable protonated aziridine. However, a more detailed study is required to prove the suggested structure. The formation of both an oxetane and aziridine isomeric ions by a ring closure as proposed in Scheme $\mathbf{1}$ is also reasoned by the fact that the exchangeable hydrogens rather than the $\mathrm{C}-\mathrm{H}$ hydrogens have been eliminated for the $\mathrm{H}_{2} \mathrm{O}$ loss. This $\mathrm{H}_{2} \mathrm{O}$ loss is confirmed by the product-ion spectra of the $\mathrm{H}-\mathrm{D}$ exchanged analogs (Scheme 1, the $\mathrm{m} / \mathrm{z}$ values observed for the deuterium-labeling compound are shown in parentheses).

Since the major ions at $m / z 264\left(\underline{\mathbf{e}}_{3 \mathrm{~b}^{\prime \prime}}\right)$ and $372\left(\underline{\mathrm{d}}_{1 \mathrm{a}}\right)$ respectively reflect the long-chain base and fatty acid 


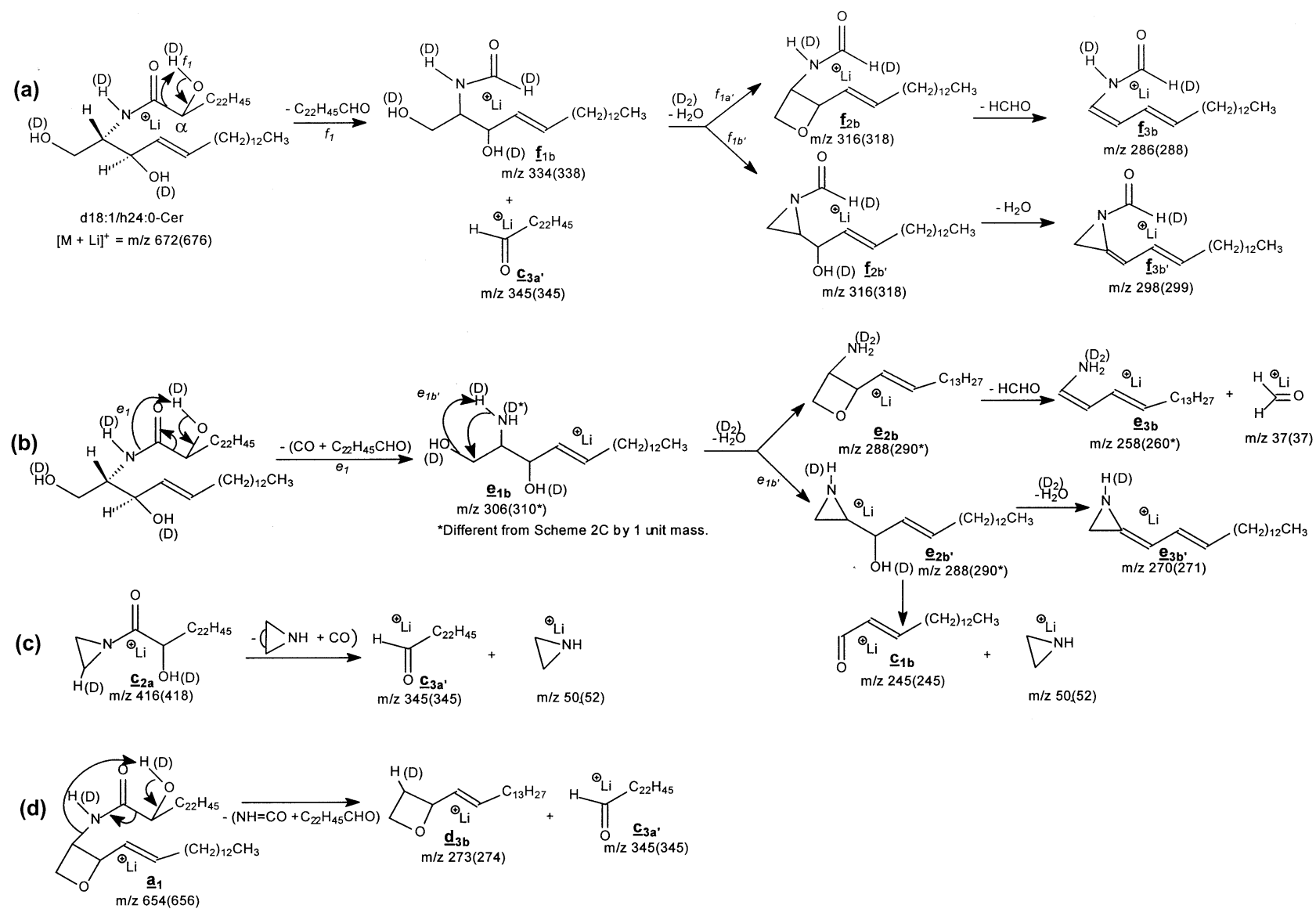

Ion designation: symbols with subscript a are fatty acid-related ions. symbols with subscript $\mathbf{b}$ are long chain base-related ions.

Scheme 2

moieties of the molecule, the structure of the compound can be easily identified. In addition, the presence of the ions at $\mathrm{m} / \mathrm{z} 398\left(\underline{\mathrm{c}}_{2 \mathrm{a}}\right)$ and $354\left(\underline{\mathrm{d}}_{2 \mathrm{a}}\right)$ in the spectrum confirms that the fatty acid substituent of the molecule is $24: 1$, whereas the d18:1-LCB can be confirmed by the presence of the ions at $m / z 245\left(\underline{\mathrm{c}}_{1 \mathrm{~b}}\right), 289\left(\underline{\mathrm{d}}_{1 \mathrm{~b}}+\underline{\mathrm{d}}_{1 \mathrm{~b}}\right), 271$ $\left(\underline{\mathrm{d}}_{2 \mathrm{~b}}\right), 288\left(\underline{\mathrm{e}}_{2 \mathrm{~b}}+\underline{\mathrm{e}}_{2 \mathrm{~b}}\right), 258\left(\underline{\mathrm{e}}_{3 \mathrm{~b}}\right), 259\left(\underline{\mathrm{d}}_{2 \mathrm{~b}}\right), 270\left(\underline{\mathrm{e}}_{3 \mathrm{~b}}\right)$, and $282\left(\mathrm{e}_{4 \mathrm{~b}}\right)$. A similar pattern of the ions was also observed for the $[\mathrm{M}+\mathrm{Li}]^{+}$ions of d18:1/18:0-Cer $(\mathrm{m} / \mathrm{z}$ 572, Figure 1c), d18:1/24:0-Cer $(\mathrm{m} / \mathrm{z}$ 656, Figure $1 \mathrm{~d})$, d18:0/18:0-Cer $(m / z$ 574, Figure 1 e), and of d18:0/24:0Cer $(m / z 658$, Figure 1f). Figure $1 \mathrm{c}$ and e show abundant ions at $m / z 316\left(\underline{c}_{2 a}\right), 290\left(\underline{d}_{1 a}\right)$, and $272\left(\underline{d}_{2 a}\right)$ that reflect the stearic acid moiety of the molecules, and Figure $1 \mathrm{~d}$ and $\mathrm{f}$ contain ions at $\mathrm{m} / \mathrm{z} 400\left(\underline{\mathrm{c}}_{2 \mathrm{a}}\right), 374\left(\underline{\mathrm{d}}_{1 \mathrm{a}}\right)$, and 356 $\left(\underline{\mathrm{d}}_{2 \mathrm{a}}\right)$, reflecting the tetracosanoic acid. The identity of the LCBs for both the lithiated d18:1/18:0-Cer (Figure 1c) and d18:1/24:0-Cer (Figure 1d) is reflected by the prominent ions at $m / z 264\left(\underline{\mathrm{e}}_{3 \mathrm{~b}^{\prime \prime}}\right)$, together with the aforementioned ions that are characteristic of d18:1LCB, whereas the d18:0-LCB for both the lithiated d18:0/18:0-Cer (Figure 1e) and d18:0/24:0-Cer (Figure 1f) is identified by the abundant ion at $m / z 291\left(\underline{d}_{1 b}+\right.$ $\left.\underline{\mathrm{d}}_{1 \mathrm{~b}}\right)$ together with ions at $m / z 266\left(\underline{\mathrm{e}}_{3 \mathrm{~b}^{\prime \prime}}\right), m / z 247\left(\underline{\mathrm{c}}_{1 \mathrm{~b}}\right)$, $273\left(\underline{\mathrm{d}}_{2 \mathrm{~b}}\right), 308\left(\underline{\mathrm{e}}_{1 \mathrm{~b}}\right), 290\left(\underline{\mathrm{e}}_{2 \mathrm{~b}}+\underline{\mathrm{e}}_{2 \mathrm{~b}}\right), 272\left(\underline{\mathrm{e}}_{3 \mathrm{~b}}\right), 261\left(\underline{\mathrm{d}}_{2 \mathrm{~b}}\right)$, and $284\left(\underline{e}_{4 b}\right)$, which are two units higher than the analogous ions observed for d18:1-LCB.

The apparent distinction of the product-ion spectra of $\mathrm{d} 18: 0 / \mathrm{nFA}-\mathrm{Cer}$ from that of $\mathrm{d} 18: 1 / \mathrm{nFA}-\mathrm{Cer}$ is that the $\left[\mathrm{M}+\mathrm{Li}-\mathrm{H}_{2} \mathrm{O}-\mathrm{HCHO}^{+}\left(\underline{\mathrm{a}}_{2}\right)\right.$ ions are the most prominent for d18:1/nFA-Cer (Figure $a, b, c$, and d), while the $\left[\mathrm{M}+\mathrm{Li}-\mathrm{H}_{2} \mathrm{O}\right]^{+}\left(\underline{a}_{1}\right)$ ions are the most abundant for d18:0/nFA-Cer (Figure 1e and f) (Table 1), when obtained at the same collision energy $(50 \mathrm{eV})$. The saturation of the LCB bond also results in the decline of the $\mathbf{e}_{3 b^{\prime \prime}}$ ion at $m / z 266$ and the $\underline{\mathbf{e}}_{3 b^{\prime}}$ ion at $m / z 272$ (the $m / z$ 272 ion in Figure 1e is also a $\underline{d}_{2 a}$ ion), and accounts for the absence of the $\underline{\mathrm{e}}_{3 \mathrm{~b}}$ ion of $m / z 260$ for d18:0/nFA-Cer. This is attributable to the fact that ions of $\underline{\mathrm{a}}_{2}, \mathrm{~m} / \mathrm{z} 272$ $\left(\underline{\mathrm{e}}_{3 \mathrm{~b}}\right), \mathrm{m} / \mathrm{z} 266\left(\underline{\mathrm{e}}_{3 \mathrm{~b}^{\prime \prime}}\right)$, and $m / z 260\left(\underline{\mathrm{e}}_{3 \mathrm{~b}}\right)$ arising from d18:0/FA-Cer are less conjugated and less stable than the corresponding ions of $\mathbf{a}_{2}$, the $m / z 270\left(\underline{e}_{3 \mathrm{~b}}\right), 264\left(\underline{e}_{3 b^{\prime \prime}}\right)$, and $258\left(\mathrm{e}_{3 \mathrm{~b}}\right)$, arising from d18:1/nFA-Cer (panel a, b, c, and $\mathrm{d}$ ). The disparities of the product-ion spectra among the d18:1- and d18:0-LCB subclasses of glycosphingolipids were previously reported and have the implication for differentiation of cerebroside isomers [24]. Another feature in the product-ion spectra of the 


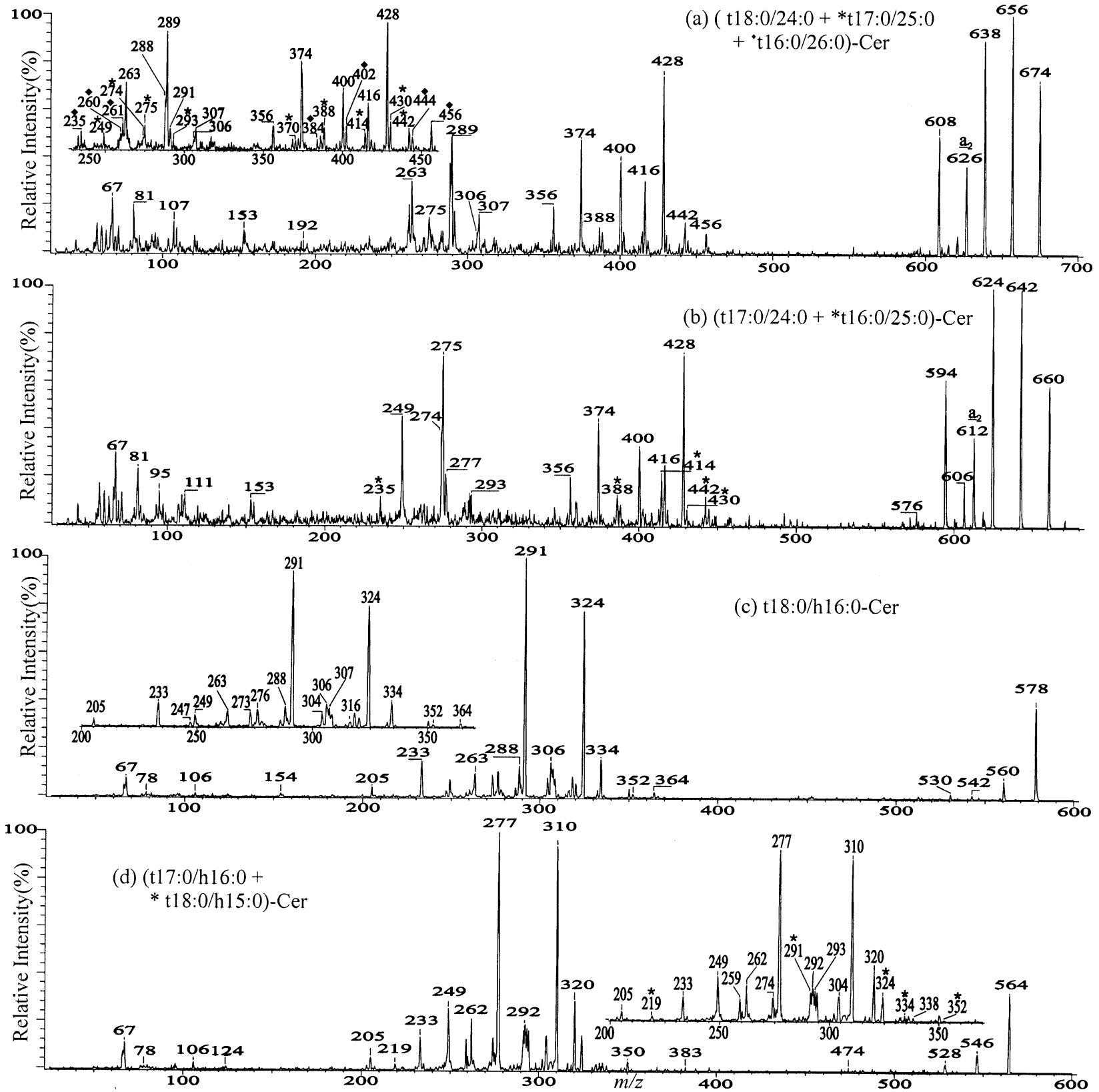

Figure 5. The product-ion spectra of the $[\mathrm{M}+\mathrm{Li}]^{+}$ions of (a) (t18:0/24:0 $+{ }^{*} \mathrm{t} 17: 0 / 25: 0+$ -t16:0/26:0)-Cer at $m / z$ 674, (b) (t17:0/24:0 + *t16:0/25:0)-Cer at $m / z$ 660, (c) t18:0/h16:0-Cer at $m / z$ 578, and (d) (t17:0/h16:0 $+{ }^{*}$ t18:0/h15:0)-Cer at $\mathrm{m} / \mathrm{z}$ 564. Ions marked with an asterisk and a superior filled diamond are the analogous ions arising from the second and the third isomer, respectively.

$[\mathrm{M}+\mathrm{Li}]^{+}$ions of $\mathrm{d} 18: 0 / \mathrm{nFA}-\mathrm{Cer}$ is that the $\mathrm{m} / \mathrm{z} 291$ ion $\left(\underline{\mathrm{d}}_{1 \mathrm{~b}}+\underline{\mathrm{d}}_{1 \mathrm{~b}}\right)$ is of abundance and a protonated amide ion at $284\left(\mathrm{C}_{17} \mathrm{H}_{35} \mathrm{CONH}_{3}^{+}\right)$and $m / z 368\left(\mathrm{C}_{23} \mathrm{H}_{47} \mathrm{CONH}_{3}^{+}\right)$is present, respectively, in the spectrum of $\mathrm{d} 18: 0 / 18: 0-\mathrm{Cer}$ (Figure 1e) and of d18:0/24:0-Cer (Figure 1f). This may be attributable to the fact that the ketene loss (Scheme 1c) to yield a stable conjugated ion species is a more favorable fragmentation pathway than the $\mathrm{C} 2-\mathrm{N}$ bond cleavage (Scheme 1b) for d18:1/nFA-Cer. However, this pathway becomes less favorable for the lithiated d18:0/ nFA-Cer, in which the analogous ions that are less conjugated are formed. As a result, the $\mathrm{C} 2-\mathrm{N}$ bond cleavage pathway leading to the formation of the $\mathrm{m} / \mathrm{z}$ 291 ion prevails.

$N$ - $\alpha$-hydroxyacylsphing-4-enines (d18:1/hFA-Cer) and $N$ - $\omega$-hydroxyacylsphing-4-enines

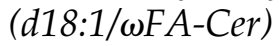

Under the same collision energy, the lithiated $N-\alpha-$ hydroxyacylsphingenines undergo more extensive fragmentations than the corresponding ions arising from $\mathrm{N}$-acylsphingenines. As illustrated in Figure 4a, the 


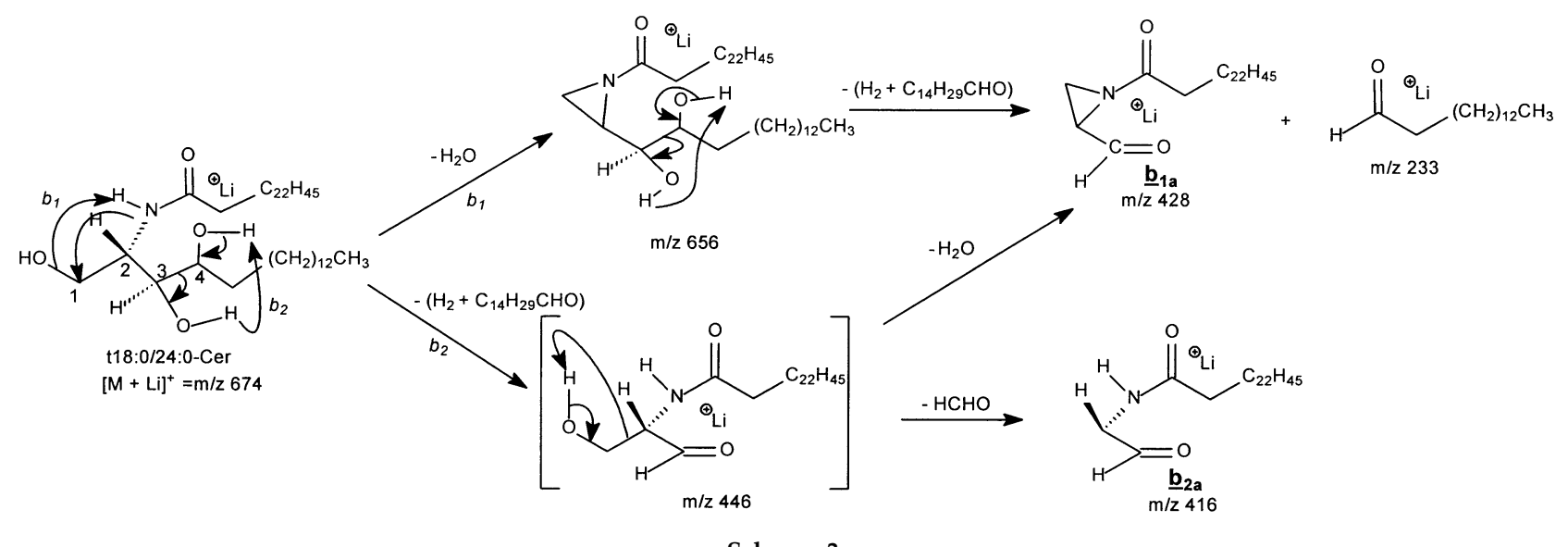

product-ion spectrum of the lithiated $\mathrm{d} 18: 1 / \mathrm{h} 24: 0-\mathrm{Cer}$ at $m / z 672$ contains common ions at $m / z 654([\mathrm{M}+\mathrm{Li}-$ $\left.\left.\mathrm{H}_{2} \mathrm{O}\right]^{+}\right)\left(\underline{\mathrm{a}}_{1}\right), 636\left(\left[\mathrm{M}+\mathrm{Li}-2 \mathrm{H}_{2} \mathrm{O}\right]^{+}\right)\left(\underline{\mathrm{a}}_{1}-\mathrm{H}_{2} \mathrm{O}\right)$, and $624\left(\left[\mathrm{M}+\mathrm{Li}-\mathrm{H}_{2} \mathrm{O}-\mathrm{HCHO}^{+}\right)\left(\mathrm{a}_{2}\right)\right.$. However, ions that are characteristic to this subclass arise from the cleavages initiated by the $\alpha$-hydroxyl group of the $N$-acyl chain [18] (Scheme 2). The elimination of the fatty acyl substituent as an aldehyde yields a weak peak of $m / z 334$ ion $\left(\underline{f}_{1 b}\right)$, corresponding to a lithiated $N$ formylsphingosine (Scheme $\mathbf{2 a}$, route $f_{1}$ ). This elimination is consistent with the observation of a lithiated aldehyde at $m / z 345\left(\left[\mathrm{C}_{22} \mathrm{H}_{45} \mathrm{CHO}+\mathrm{Li}\right]^{+}\right)\left(\underline{c}_{3 a}\right)$, which is diagnostic to the fatty acyl chain of this subclass. The prior formation of the lithiated $N$-formylsphingosine ion of $m / z 334\left(\underline{f}_{1 b}\right)$ to the $m / z 316$ ion is reasoned by the fact that the $m / z 286$ and 298 ions were also observed in the spectrum. The $m / z 316$ is probably a lithiated oxetane or a lithiated aziridine ion arising from a $\mathrm{H}_{2} \mathrm{O}$ loss from $\mathrm{m} / \mathrm{z} 334$ via the similar fragmentation processes as described earlier (Scheme 2a). The oxetane ion of $m / z 316\left(\underline{f}_{2 b}\right)$ dissociates to the $m / z 286$ ion $\left(\underline{f}_{3 b}\right)$ by loss of HCHO (route $\left.f_{1 a^{\prime}}\right)$. The aziridine ion of $m / z 316\left(\underline{f}_{2 b^{\prime}}\right)$ undergoes another $\mathrm{H}_{2} \mathrm{O}$ loss to give the $m / z 298\left(\underline{f}_{3 b^{\prime}}\right)$ (route $f_{1 b^{\prime}}$ ).

The bond cleavage facilitated by the $\alpha$-hydroxyl of the $N$-acyl chain is further evidenced by the presence of a base peak of $m / z 306$, arising from a combined losses of $\mathrm{CO}$ and $\mathrm{C}_{22} \mathrm{H}_{45} \mathrm{CHO}$ from $\mathrm{m} / z 672$ (Scheme $2 \mathbf{b}$, route $e_{1}$ ) [18]. This fragmentation pathway is consistent with the observation of the analogous ion of $\mathrm{m} / \mathrm{z} 310$ ion arising from the $d_{4}$-d18:1/h24:0-Cer at m/z 676 (Figure $4 b)$. The $m / z 306\left([\mathrm{M}+\mathrm{Li}]^{+}-\mathrm{CO}-\mathrm{C}_{22} \mathrm{H}_{45} \mathrm{CHO}\right)\left(\underline{\mathrm{e}}_{1 \mathrm{~b}}\right)$ ion is a lithiated sphingosine ion, which undergoes further fragmentations by the same pathways as described in Scheme 1c. This is supported by the production spectrum of $\mathrm{d}_{4}$-d18:1/h24:0-Cer (Figure $4 \mathrm{~b}$ ), in which the analogous ions resulting from further dissociations of the $m / z 310$ ion have a two-unit mass shift, consistent with the suggested mechanism (Scheme $\mathbf{2 b}$ ).

Ions that identify the h24:0 fatty acyl substituent were observed at $m / z 416\left(\underline{c}_{2 a}\right)$ and $390\left(\underline{\mathrm{d}}_{1 \mathrm{a}}\right)$, analogous to those observed for $N$-acylsphingosines. Because of the presence of the $\alpha$-hydroxyl group, the $m / z 416$ ion may dissociate into the lithiated aldehyde ion at $m / z 345$ $\left(\underline{c}_{3 a}\right)$, by elimination of $\mathrm{CO}$ and $\mathrm{HNCH}_{2} \mathrm{CH}_{2}$ simultaneously (Scheme $\mathbf{2 c}$ ). This elimination is consistent with the observation of a lithiated aziridine $\left(\left[\mathrm{HNCH}_{2} \mathrm{CH}_{2}+\right.\right.$ $\mathrm{Li}]^{+}$) at $m / z 50$, which is only observed for this subclass (Figure $4 a, b, c, d, e$, and f). A weak ion probably arising from further dissociation of $m / z 654$ by expulsion of $\mathrm{NH}=\mathrm{CO}$ and $\mathrm{C}_{22} \mathrm{H}_{45} \mathrm{CHO}$ was observed at $m / z 273\left(\underline{\mathrm{d}}_{3 \mathrm{~b}}\right)$ (Scheme 2d). However, an analogous ion of $\mathrm{m} / \mathrm{z} 291$ becomes the most prominent in the product-ion spectra of the lithiated t18:0/hFA-Cer (discussed later). The proposed pathways for the fragmentations (Scheme 2) are further supported by the product-ion spectrum of the $[\mathrm{M}+\mathrm{Li}]^{+}$ions of $\mathrm{d}_{4}-\mathrm{d} 18: 1 / \mathrm{h} 24: 0-C e r$ at $m / z 676$ (Figure $4 \mathrm{~b}$ ), which yields the analogous ions with the expected mass shifts. A similar pattern of ions was also observed for the $[\mathrm{M}+\mathrm{Li}]^{+}$ions of $\mathrm{d} 17: 1 / \mathrm{h} 16: 0-\mathrm{Cer}(\mathrm{m} / \mathrm{z}$ 546 , Figure $4 \mathrm{c})$, and of d18:1/h16:0-Cer $(\mathrm{m} / \mathrm{z} 560$, Figure $4 \mathrm{~d})$. The $\alpha$-hydroxypalmitoyl moiety of the two compounds is reflected by the prominent ion at $m / z 233$ $\left(\underline{c}_{3 a}\right)$, and the presence of the $m / z 304\left(\underline{c}_{2 a}\right)$ and $278\left(\underline{d}_{1 a}\right)$ ions in the mass spectra. The 17:1-LCB of the former is identified by the prominent ions of $m / z 292\left(\underline{e}_{1 b}\right), 284$ $\left(\underline{f}_{3 b^{\prime}}\right), 274\left(\underline{e}_{2 b}+\underline{e}_{2 b^{\prime}}\right)$, and $244\left(\underline{e}_{3 b}\right)$ along with the presence of the ions at $m / z 250\left(\underline{e}_{3 b^{\prime \prime}}\right)$ and $302\left(\underline{f}_{2 b}+\underline{f}_{2 b^{\prime}}\right)$. The latter spectrum contains ions at $m / z 306\left(\underline{\mathrm{e}}_{1 \mathrm{~b}}\right), 298$ $\left(\underline{\mathrm{f}}_{3 \mathrm{~b}^{\prime}}\right), 288\left(\underline{\mathrm{e}}_{2 \mathrm{~b}}+\underline{\mathrm{e}}_{2 \mathrm{~b}^{\prime}}\right), 258\left(\underline{\mathrm{e}}_{3 \mathrm{~b}}\right), m / z 264\left(\underline{\mathrm{e}}_{3 \mathrm{~b}^{\prime \prime}}\right)$, and 316 $\left(\underline{f}_{2 b}+\underline{f}_{2 b}\right)$, which are 14 Da higher and are diagnostic ions for $N$ - $\alpha$-hydroxyacylsphingosines.

As described earlier, the saturation of the LCB in the $N$ - $\alpha$-acylsphinganines results in the decline of the $\underline{\mathrm{a}}_{2}$ $\left(\left[\mathrm{M}+\mathrm{Li}-\mathrm{H}_{2} \mathrm{O}-\mathrm{HCHO}^{+}\right), \underline{\mathrm{e}}_{3 \mathrm{~b}}, \underline{\mathrm{e}}_{3 \mathrm{~b}^{\prime}}\right.$ and $\underline{\mathrm{e}}_{3 \mathrm{~b}^{\prime \prime}}$ ions. These features are also observed for $N$ - $\alpha$-hydroxyacylsphinganines, and permit their distinction from $N-\alpha-$ hydroxyacylsphingosines. This is exemplified by the product-ion spectra of the $[\mathrm{M}+\mathrm{Li}]^{+}$ions of $\mathrm{d} 18: 0 / \mathrm{h} 16$ : 0 -Cer at $m / z 562$ (Figure $4 \mathrm{e}$ ), and of d17:0/h16:0 at $\mathrm{m} / \mathrm{z}$ 548 (Figure $4 \mathrm{f})$. The $m / z 514\left(\underline{\mathrm{a}}_{2}\right)$ and $260\left(\underline{\mathrm{e}}_{3 \mathrm{~b}}\right)$ ions are of low abundance and ions at $m / z 266\left(\underline{\mathrm{e}}_{3 \mathrm{~b}^{\prime \prime}}\right)$ and $272\left(\underline{\mathrm{e}}_{3 \mathrm{~b}}\right)$ are absent in the spectrum of the former (Figure $4 \mathrm{e}$ ). A similar result was also observed for the analogous ions of $m / z 500\left(\underline{\mathrm{a}}_{2}\right), 246\left(\underline{\mathrm{e}}_{3 \mathrm{~b}}\right), 252\left(\underline{\mathrm{e}}_{3 \mathrm{~b}^{\prime \prime}}\right)$, and $258\left(\underline{\mathbf{e}}_{3 \mathrm{~b}^{\prime}}\right)$ in the 


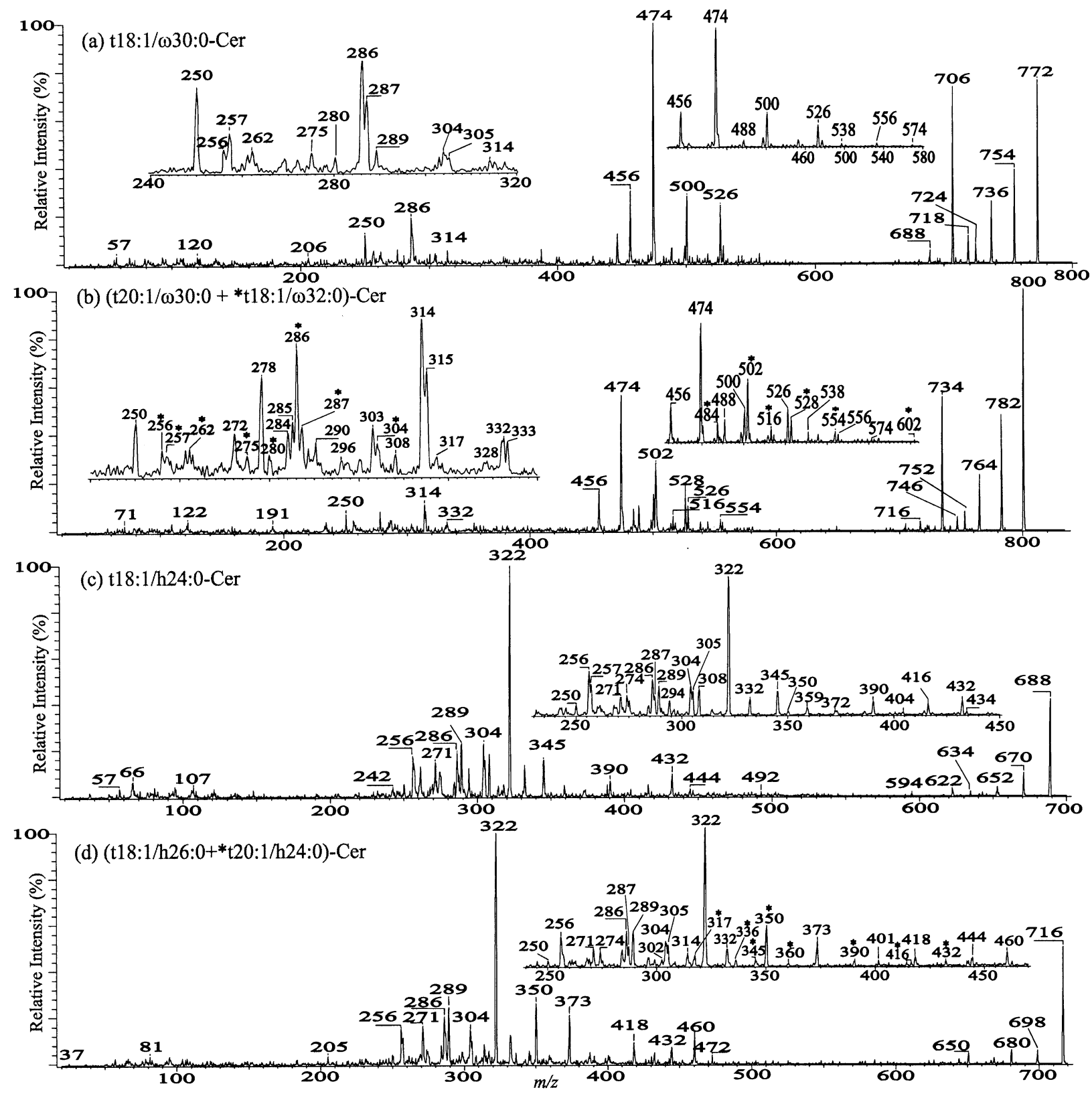

Figure 6. The product-ion spectra of the $[\mathrm{M}+\mathrm{Li}]^{+}$ions of (a) $\mathrm{t} 18: 1 / \omega 30: 0-\mathrm{Cer}$ at $\mathrm{m} / \mathrm{z} 772$, (b) (t20:1/ $\left.\omega 30: 0+{ }^{*} \mathrm{t} 18: 1 / \omega 32: 0\right)-C e r$ at $m / z$ 800, (c) t18:1/h24:0-Cer at $m / z 688$, and of (d) $(\mathrm{t} 18: 1 / \mathrm{h} 26: 0+$ *t20:1/h24:0)-Cer at $m / z$ 716. Again, the presence of the $\alpha$-hydroxy group in fatty acyl moiety (panels c and d) facilitates the fragmentations. The ions arising from the minor isomeric species are marked with an asterisk.

latter spectrum (Figure $4 \mathrm{f})$. The low abundance of the $\underline{a}_{2}$ ion observed for the two spectra is also consistent with the decline of $m / z 37$, a $\left[\mathrm{HCHO}+\mathrm{Li}^{+}\right.$ion.

While the $[\mathrm{M}+\mathrm{Li}]^{+}$ions of $\mathrm{d} 18: 1 / \mathrm{hFA}-$ Cer undergo vigorous fragmentations because of the presence of the $\alpha$-hydroxyl in the fatty acid substituent, the d18:1/ $\omega$ FACer undergoes fragmentations similar to that described for $\mathrm{d} 18: 1 / \mathrm{nFA}-\mathrm{Cer}$. This is illustrated by the production spectrum of the $[\mathrm{M}+\mathrm{Li}]^{+}$ions of d18:1/ $\omega 30: 0-\mathrm{Cer}$ at $\mathrm{m} / \mathrm{z} 756$ (Figure $4 \mathrm{~g}$ ). The identity of the $\omega$-hydroxy fatty acyl substituent of the compound is revealed by the presence of the prominent ions at $m / z 500\left(c_{2 a}\right), 474$ $\left(\underline{\mathrm{d}}_{1 \mathrm{a}}\right)$, and $456\left(\underline{\mathrm{d}}_{2 \mathrm{a}}\right)$. These ions are more abundant than the analogous ions observed for d18:1/nFA-Cer, attributable to the $\omega$-hydroxyl group in the fatty acid substituent. In contrast, the ions at $\mathrm{m} / \mathrm{z} 264\left(\mathrm{e}_{3 b^{\prime \prime}}\right), \mathrm{m} / \mathrm{z} 289$ $\left(\underline{\mathrm{d}}_{1 \mathrm{~b}}+\underline{\mathrm{d}}_{1 \mathrm{~b}}\right), 288\left(\underline{\mathrm{e}}_{2 \mathrm{~b}}+\underline{\mathrm{e}}_{2 \mathrm{~b}}\right), 259\left(\underline{\mathrm{d}}_{2 \mathrm{~b}}\right) 258\left(\underline{\mathrm{e}}_{3 \mathrm{~b}}\right), 282\left(\underline{\mathrm{e}}_{4 \mathrm{~b}}\right)$, $270\left(\underline{e}_{3 \mathrm{~b}}\right), 271\left(\underline{\mathrm{d}}_{2 \mathrm{~b}}\right)$, and $245\left(\underline{\mathrm{c}}_{1 \mathrm{~b}}\right)$ that identify the d18:1-LCB are less abundant than the same ions observed for d18:1/nFA-Cer. A similar pattern of ions was observed for the lithiated d20:1/ $\omega 30: 0-C e r$ at $\mathrm{m} / \mathrm{z} 784$ (Figure $4 \mathrm{~h}$ ), which is also composed of a minor d18:1/ 


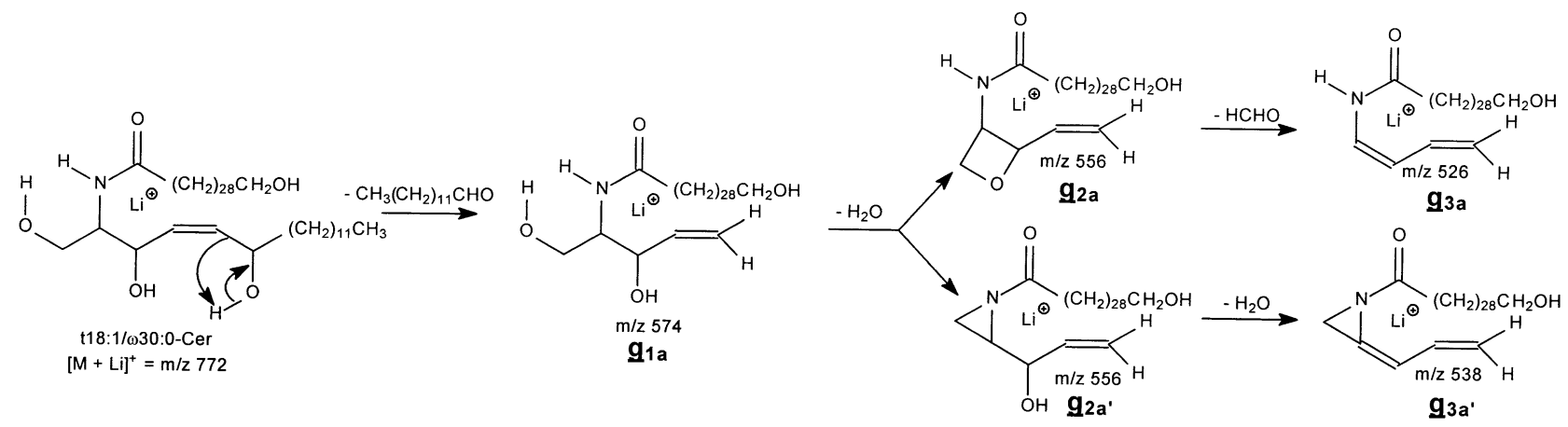

Scheme 4

$\omega 32: 0-C e r$ isomer. The $\mathrm{d} 20: 1 / \omega 30: 0-$ Cer component is identified by the prominent ions of $292\left(\underline{e}_{3 b^{\prime \prime}}\right), 298\left(\underline{e}_{3 b^{\prime}}\right)$, $299\left(\underline{\mathrm{d}}_{2 \mathrm{~b}}\right), 316\left(\underline{\mathrm{e}}_{2 \mathrm{~b}}+\underline{\mathrm{e}}_{2 \mathrm{~b}}\right)$, and $273\left(\underline{\mathrm{c}}_{1 \mathrm{~b}}\right)$, reflecting the $\mathrm{d} 20: 1-\mathrm{LCB}$, in combination with ions at $m / z 500\left(\underline{c}_{2 \mathrm{a}}\right), 474$ $\left(\underline{\mathrm{d}}_{1 \mathrm{a}}\right)$, and $456\left(\underline{\mathrm{d}}_{2 \mathrm{a}}\right)$, which reflect the $\omega 30: 0-\mathrm{FA}$, whereas the $\mathrm{d} 18: 1 / \omega 32: 0-C e r$ isomer is identified by the presence of the $m / z 528\left(\underline{\mathrm{c}}_{2 \mathrm{a}}\right), 502\left(\underline{\mathrm{d}}_{1 \mathrm{a}}\right), 484\left(\underline{\mathrm{d}}_{2 \mathrm{a}}\right), 264\left(\underline{\mathrm{e}}_{3 \mathrm{~b}^{\prime \prime}}\right), 288$ $\left(\underline{\mathrm{e}}_{2 \mathrm{~b}}+\underline{\mathrm{e}}_{2 \mathrm{~b}^{\prime}}\right)$, and the $245\left(\underline{\mathrm{c}}_{1 \mathrm{~b}}\right)$ ions in the spectrum.

\section{N-acyl-4-hydroxysphinganine (N-acylphytosphingo- sine) and $N$ - $\alpha$-hydroxyacyl-4-hydroxysphinganine (N- $\alpha$-hydroxyacylphytosphingosine)}

As shown in Figure $5 \mathrm{a}$, the $[\mathrm{M}+\mathrm{Li}]^{+}$ion of $N$ tetradodecanoylphytosphingosine (t18:0/24:0-Cer) at $\mathrm{m} / \mathrm{z} 674$ yields a product-ion spectrum distinguishable from that obtained from the sphingosine subclass. The $\underline{\mathrm{a}}_{1}, \underline{\mathrm{a}}_{2},\left(\underline{\mathrm{a}}_{1}-\mathrm{H}_{2} \mathrm{O}\right)$, and $\left(\underline{\mathrm{a}}_{2}-\mathrm{H}_{2} \mathrm{O}\right)$ series ions at $m / z$ 656, 626,638 , and 608 are abundant, and the $\underline{a}_{2}$ ion of $\mathrm{m} / \mathrm{z} 626$ $(656-\mathrm{HCHO})$ is less abundant than its precursor ion at $m / z 656$, a reversal from that observed for $\mathrm{d} 18: 1 / \mathrm{nFA}$ Cer (Figure 1a, b, c, and d). This is consistent with the fact that the $\underline{a}_{2}$ ion from $\mathrm{d} 18: 1 / \mathrm{nFA}-\mathrm{Cer}$ possesses an additional double bond at C- 4 of the LCB and results in a conjugated bond, which is stable. Another feature in the product-ion spectra of this subclass is that the $\left(\underline{a}_{2}-\right.$ $\mathrm{H}_{2} \mathrm{O}$ ) ion at $m / z 608$ is also abundant. This is attributed to the fact that the additional hydroxyl group at C-4 of the $\mathrm{LCB}$, can participate in an additional $\mathrm{H}_{2} \mathrm{O}$ loss and results in a stable conjugated ion, which is analogous to the $\underline{\mathrm{a}}_{2}$ ion observed for $\mathrm{d} 18: 1 / \mathrm{nFA}-\mathrm{Cer}$.

Several prominent ions unique to this subclass were observed at $m / z 428\left(\underline{b}_{1 \mathrm{a}}\right)$ and $416\left(\underline{\mathrm{b}}_{1 \mathrm{~b}}\right)$. The $\mathrm{m} / \mathrm{z} 428$ ion $\left(\underline{b}_{1 \mathrm{a}}\right)$ may arise from the lithiated aziridine intermediate of $m / z 656\left(\underline{\mathbf{b}}_{1}\right)$, by cleaving the C-C bond of the 3,4-diol of the LCB (Scheme 3 ). This cleavage also results in a weak ion at $m / z$ 233, corresponding to a lithiated aldehyde $\left(\left[\mathrm{C}_{14} \mathrm{H}_{29} \mathrm{CHO}+\mathrm{Li}^{+}\right)\right.$. Another proposed pathway for formation of the $\mathrm{m} / \mathrm{z} 428$ ion involves a primary cleavage of the same bond of the lithiated t18:0/24:0-Cer ion of $m / z 674$ to a $m / z 446$ intermediate (not seen) by loss of an aldehyde and $\mathrm{H}_{2}$, followed by a $\mathrm{H}_{2} \mathrm{O}$ or $\mathrm{HCHO}$ loss to yield the $\mathrm{m} / \mathrm{z} 428$ or 416 ion (Scheme 3). The observation of the above two ions, plus the ions at $m / z 400\left(\underline{\mathrm{c}}_{2 \mathrm{a}}\right), 374\left(\underline{\mathrm{d}}_{1 \mathrm{a}}\right)$, and $356\left(\underline{\mathrm{d}}_{2 \mathrm{a}}\right)$ (Scheme 1b), commonly observed for 24:0-FA, easily identifies the fatty acyl constituent of the molecule, whereas the identity of the phytosphingosine can be determined by the presence of the $m / z 288\left(\underline{e}_{3 b^{\prime}}\right), 289\left(\underline{d}_{2 b}\right), 263\left(\underline{c}_{1 b}\right), 307$ $\left(\underline{\mathrm{d}}_{1 \mathrm{~b}}+\underline{\mathrm{d}}_{1 \mathrm{~b}}\right)$, and $306\left(\underline{\mathrm{e}}_{2 \mathrm{~b}}+\underline{\mathrm{e}}_{2 \mathrm{~b}}\right)$ ions. In the same spectrum, a set of the masses at $m / z 442,430,414,388$, and 370 , which reflect the 25:0-FA (the masses are 14-Da higher than the corresponding ions arising from 24:0FA) were also observed, along with ions at $m / z 274\left(\underline{e}_{3 b^{\prime}}\right)$, $275\left(\underline{\mathrm{d}}_{2 \mathrm{~b}}\right), 293\left(\underline{\mathrm{d}}_{1 \mathrm{~b}}+\underline{\mathrm{d}}_{1 \mathrm{~b}}\right)$, and $249\left(\underline{\mathrm{c}}_{1 \mathrm{~b}}\right)$, arising from t17:0-LCB. These ions clearly demonstrate that the lithiated molecular species of $m / z 674$ also contains a t17:0/ 25:0-Cer isomer. A minor t16:0/26:0-Cer isomer is also present in the spectrum. This is revealed by the masses of $m / z 456,444,428$ (overlap with the $\underline{b}_{1 a}$ ions from t18:0/24:0-Cer), 402, and 384, which reflect the 26:0-FA and the masses that reflect the t16:0-LCB at $m / z 235\left(\underline{c}_{1 b}\right)$, $260\left(\underline{e}_{3 b}\right)$, and $261\left(\underline{d}_{2 b}\right)$. Figure $5 b$ illustrates the production spectrum of the $m / z 660$ ion, which also contains two sets of the ions arising from a major lithiated t17:0/24: 0 -Cer species and from a minor component of $t 16: 0 / 25$ : 0 -Cer.

The concept that the $\alpha$-hydroxyl group in the $N$-acyl chain facilitates the decompositions of ceramides is further evidenced by the product-ion spectra of $N-\alpha$ hydroxyacylphytosphingosines. As illustrated in Figure $5 \mathrm{c}$, the product-ion spectrum of the $[\mathrm{M}+\mathrm{Li}]^{+}$ion of $\mathrm{N}$ - $\alpha$-hydroxypalmitoylphytosphingosine (t18:0/h16:0Cer) at $m / z 578$ contains weak ions at $m / z 560([\mathrm{M}+\mathrm{Li}$ $\left.\left.-\mathrm{H}_{2} \mathrm{O}\right]^{+}\right)\left(\underline{\mathrm{a}}_{1}\right), 542\left(\left[\mathrm{M}+\mathrm{Li}-2 \mathrm{H}_{2} \mathrm{O}\right]^{+}\right)\left(\underline{\mathrm{a}}_{1}-\mathrm{H}_{2} \mathrm{O}\right)$, and $530\left(\left[\mathrm{M}+\mathrm{Li}-\mathrm{H}_{2} \mathrm{O}-\mathrm{HCHO}^{+}\right)\left(\underline{\mathrm{a}}_{2}\right)\right.$. The $m / z 304\left(\underline{\mathrm{c}}_{2 \mathrm{a}}\right)$ and $233\left(\underline{c}_{3 a^{\prime}}\right)$ ions that reflect the h16:0-FA, are of low abundance. In contrast, the analogous ions observed in the spectra of $N$-tetradodecanoylphytosphingosine are among the most prominent (Figure $5 \mathrm{a}$ and $\mathrm{b}$ ).

The major fragmentation pathways for the lithiated t18:0/h16:0-Cer appear to arise from cleavage of the amide $\mathrm{N}-\mathrm{CO}$ bond, resulting in a prominent ion at $\mathrm{m} / \mathrm{z}$ $324\left([\mathrm{M}+\mathrm{Li}]^{+}-\mathrm{CO}-\mathrm{C}_{14} \mathrm{H}_{29} \mathrm{CHO}\right)\left(\underline{\mathrm{e}}_{1 \mathrm{~b}}\right)$. This is followed by a $\mathrm{H}_{2} \mathrm{O}$ loss to yield an aziridine $\left(\underline{\mathrm{e}}_{2 \mathrm{~b}}\right)$ or an oxetane $\left(\underline{\mathbf{e}}_{2 \mathrm{~b}}\right)$ ion at $m / z 306$, which successively eliminates $\mathrm{H}_{2} \mathrm{O}$ or $\mathrm{HCHO}$ to form the $m / z 288\left(\underline{\mathrm{e}}_{3 \mathrm{~b}}\right)$ or $m / z 276$ 


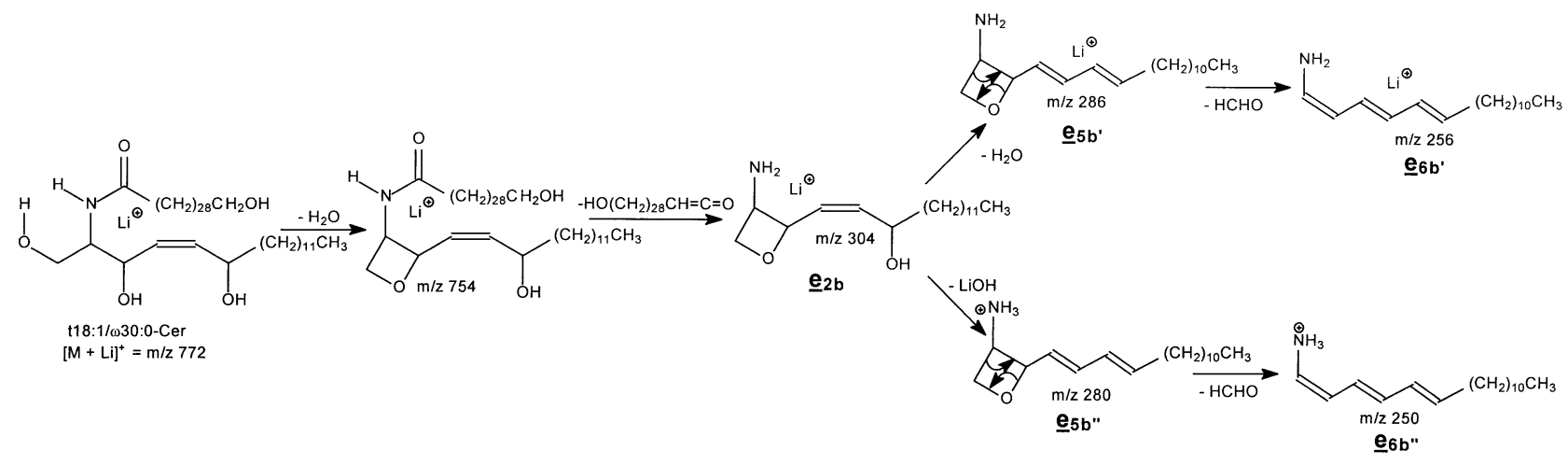

Scheme 5

$\left(\underline{\mathrm{e}}_{3 \mathrm{~b}}\right)$ ion, respectively. The ions at $m / z 352\left([\mathrm{M}+\mathrm{Li}]^{+}-\right.$ $\left.\mathrm{C}_{14} \mathrm{H}_{29} \mathrm{CHO}\right)\left(\underline{\mathrm{f}}_{1 \mathrm{~b}}\right), m / z 334\left(\underline{\mathrm{f}}_{1 \mathrm{~b}}-\mathrm{H}_{2} \mathrm{O}\right)\left(\underline{\mathrm{f}}_{2 \mathrm{~b}}+\underline{\mathrm{f}}_{2 \mathrm{~b}}\right), m / z$ $316\left(\underline{f}_{2 \mathrm{~b}}-\mathrm{H}_{2} \mathrm{O}\right)\left(\underline{f}_{3 \mathrm{~b}^{\prime}}\right)$, and $m / z 304\left(\underline{\mathrm{f}}_{2 \mathrm{~b}^{\prime}}-\mathrm{HCHO}\right)\left(\underline{f}_{3 \mathrm{~b}}\right)$ arise from the same pathways as described for $N-\alpha$ hydroxyacylsphingosines (Scheme 2a). Two sets of the masses analogous to the above ions were observed in the product-ion spectrum of $m / z 564$ (Figure $5 \mathrm{~d}$ ). The major isomer of $\mathrm{t} 17: 0 / \mathrm{h} 16: 0-\mathrm{Cer}$ is identified by the presence of the $m / z 304\left(\underline{c}_{2 a}\right)$ and $233\left(\underline{c}_{3 a}\right)$ ions, reflecting the h16:0-FA, together with ions at $m / z 338\left(\underline{f}_{1 b}\right), 320$ $\left(\underline{f}_{2 b}+\underline{f}_{2 b^{\prime}}\right), 310\left(\underline{e}_{1 b}\right), 293\left(\underline{d}_{1 b}+\underline{d}_{1 b^{\prime}}\right), 292\left(\underline{e}_{2 b^{\prime}}+\underline{e}_{2 b}\right), 277$ $\left(\underline{\mathrm{d}}_{3 \mathrm{~b}}\right), 259\left(\underline{\mathrm{d}}_{3 \mathrm{~b}}-\mathrm{H}_{2} \mathrm{O}\right)$, and $249\left(\underline{\mathrm{c}}_{1 \mathrm{~b}}\right)$ that are unique to t17:0-LCB. The minor species of the t18:0/h15:0-Cer isomer is recognized by the major ions at $m / z 352\left(\underline{f}_{1 b}\right)$, $334\left(\underline{f}_{2 b}+\underline{f}_{2 b^{\prime}}\right), 324\left(\underline{e}_{1 b}\right), 291\left(\underline{d}_{3 b}\right)$, and $219\left(\underline{c}_{3 a^{\prime}}\right)$.

The apparent distinction among the product-ion spectra of the lithiated $N$ - $\alpha$-hydroxyacylsphingosines (Figure $4 \mathrm{a}, \mathrm{b}$ and $\mathrm{d}$ ) and $N$ - $\alpha$-hydroxyacylphytosphingosines (Figure 5c, d) lies on the fact that the $\underline{d}_{3 b}$ series ion at $\mathrm{m} / \mathrm{z} 273$ for the former compounds is of low abundance, while the analogous ions at $m / z 291$ observed for $\mathrm{t} 18: 0 / \mathrm{h} 16: 0-C e r$ (Figure $5 \mathrm{c}$ ) and at $\mathrm{m} / \mathrm{z} 277$ observed for $\mathrm{t} 17: 0 / \mathrm{h} 16: 0-$ Cer (Figure $5 \mathrm{~d}$ ) are the most prominent. When subjected to CAD, the $\underline{\mathrm{d}}_{3 \mathrm{~b}}$ series ions of $\mathrm{m} / \mathrm{z} 273$ and 291 undergo further loss of $\mathrm{H}_{2} \mathrm{O}$ or HCHO (data not shown). The prominence of the $\underline{d}_{3 b}$ ions observed for the $N$ - $\alpha$-hydroxyacylphytosphingosines but not for the $N$ - $\alpha$-hydroxyacylsphingosines may indicate that further fragmentation of the $\underline{d}_{3 b}$ ion from the $N$ - $\alpha$-hydroxyacylphytosphingosines is thermodynamically less favorable than that from the $N-\alpha$ hydroxyacylsphingosines, which possess an unsaturated LCB. An analogous ion was also observed for all the ceramides with a saturated LCB that have been examined. These include the $m / z 291,277,275$, and 261 ions in the product-ion spectrum of t18:0/24:0-Cer (Figure 5a), t17:0/24:0-Cer (Figure 5b), d18:0/h16:0-Cer (Figure 4e) and of d17:0/h16:0-Cer (Figure 4f), respectively. The analogous ions, however, were of low abundance in the product-ion spectra of all the $N$-acyl-4sphingenine ceramides examined.

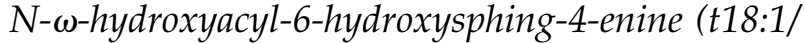
$\omega F A-C e r)$ and $N$ - $\alpha$-hydroxy-6-hydroxysphing-4enine (t18:1/hFA-Cer)

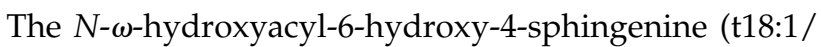
$\omega$ FA-Cer) is a protein-bound ceramide found in human stratum corneum, whereas the $N$ - $\alpha$-hydroxy-6-hydroxysphing-4-enine (t18:1/hFA-Cer) is not protein bounded. The major species of the $t 18: 1 / \omega F A-C e r$ found in human stratum corneum is $t 18: 1 / \omega 30: 0-C e r$ [6], which gives the $[\mathrm{M}+\mathrm{Li}]^{+}$ions at $m / z 772$ when subjected to ESI analysis. Upon CAD, the $m / z 772$ ion yields intense fragment ions at $m / z 754\left(772-\mathrm{H}_{2} \mathrm{O}\right), 736\left(772-2 \mathrm{H}_{2} \mathrm{O}\right)$, and $718(772-$ $\left.3 \mathrm{H}_{2} \mathrm{O}\right)$, by consecutive losses of $\mathrm{H}_{2} \mathrm{O}$. Ions at $m / z 724(754$ - HCHO), 706 (736 - HCHO), and 688 (718 - HCHO) probably arise from further loss of $\mathrm{HCHO}$ from $m / z$ 754, 736 , and 718, respectively (Figure 6a). The $m / z 688$ ion can also arise from an additional $\mathrm{H}_{2} \mathrm{O}$ loss from the $m / z 706$ ion. This $\mathrm{H}_{2} \mathrm{O}$ loss possibly eliminates the $\omega$-hydroxyl of the fatty acid substituent. The $\omega$-hydroxytriacontanoic acid moiety $(\omega 30: 0)$ was identified by the presence of the prominent ions at $m / z 500\left(\underline{\mathrm{c}}_{2 \mathrm{a}}\right), 526\left(\mathrm{~g}_{3 \mathrm{a}}\right), 474\left(\underline{\mathrm{d}}_{1 \mathrm{a}}\right)$, and 456 $\left(\underline{\mathrm{d}}_{2 \mathrm{a}}\right)$, which are also abundant in the spectra of $\mathrm{d} 18: 1 / \omega 30$ : 0-Cer (Figure 4g) and d20:1/ $130: 0-C e r$ (Figure $4 \mathrm{~h}$ ). The ions specific to this subclass arise from the decompositions initiated by the cleavage of C5-C6 bond of the LCB to a $\mathrm{m} / \mathrm{z} 574\left(\mathrm{~g}_{1 \mathrm{a}}\right)$ ion, by eliminating an aldehyde (Scheme 4). This is followed by a water loss step as described earlier, to yield both a lithiated oxetane $\left(\mathrm{g}_{2 \mathrm{a}}\right)$ and aziridine $\left(\mathrm{g}_{2 \mathrm{a}}\right)$ intermediate at $m / z 556$, which dissociates to ions of $m / z$ $526\left(\mathrm{~g}_{3 \mathrm{a}}\right)$ and $538\left(\mathrm{~g}_{3 \mathrm{a}}\right)$ by explusion of $\mathrm{HCHO}$ and $\mathrm{H}_{2} \mathrm{O}$, respectively. The t18:1-LCB is recognized by the prominent $\underline{\mathrm{e}}_{3 \mathrm{~b}^{\prime}}$ ion of $m / z 286$, which arises from $m / z 754$ ([M + $\left.\left.\mathrm{Li}-\mathrm{H}_{2} \mathrm{O}\right]^{+}\right)\left(\underline{\mathrm{a}}_{1}\right)$ by the initial loss of the $\omega$-hydroxyl fatty acid as a ketene (loss of $\mathrm{HO}\left(\mathrm{CH}_{2}\right)_{28} \mathrm{CH}=\mathrm{C}=\mathrm{O}$ ) to yield the $\mathrm{m} / \mathrm{z} 304$ ion, probably a lithiated oxetane. This is followed by a $\mathrm{H}_{2} \mathrm{O}$ or a $\mathrm{LiOH}$ loss to yield the $m / z 286\left(\underline{e}_{5 b}\right)$ or $m / z$ $280\left(\underline{e}_{5 b^{\prime \prime}}\right)$ ion, respectively (Scheme 5). These fragmentation processes also result in the $m / z 256\left(\underline{\mathbf{e}}_{6 \mathrm{~b}^{\prime}}\right)$ and $\mathrm{m} / \mathrm{z}$ $250\left(\underline{\mathrm{e}}_{6 \mathrm{~b}^{\prime \prime}}\right)$ ions by further expulsion of $\mathrm{HCHO}$ and are consistent with the idea that a lithiated oxetane intermediate was primarily formed as described earlier. 
Table 2. Minor fragment ions observed for various ceramide standards

\begin{tabular}{|c|c|c|c|c|c|c|c|c|c|c|c|c|c|c|c|c|c|c|c|c|}
\hline \multicolumn{3}{|c|}{ Ceramide species } & \multicolumn{18}{|c|}{ Fragment ions from CAD of $[\mathrm{M}+\mathrm{Li}]^{+}$} \\
\hline \multirow{2}{*}{$\begin{array}{l}{[\mathrm{M}+\mathrm{Li}]^{+}} \\
(m / z) \\
\end{array}$} & \multirow[b]{2}{*}{ Fatty acid } & \multirow[b]{2}{*}{ LCB } & \multicolumn{2}{|c|}{$\begin{array}{c}\text { common ions } \\
(\mathrm{m} / \mathrm{z})\end{array}$} & \multicolumn{4}{|c|}{ FA ions $(m / z)$} & \multicolumn{12}{|c|}{ LCB ions $(m / z)$} \\
\hline & & & $\underline{\mathrm{a}}_{2}-\mathrm{H}_{2} \mathrm{O}$ & $\underline{\underline{\mathrm{a}_{2}}}-\mathrm{LiOH}$ & $\underline{\mathbf{c}}_{1 \mathrm{a}}$ & $\mathrm{g}_{1 \mathrm{a}}$ & $\mathrm{g}_{2 \mathrm{a}}+\mathrm{g}_{2 \mathrm{a}^{\prime}}$ & $\mathrm{g}_{3 \mathrm{a}^{\prime}}$ & $\underline{\mathrm{c}}_{1 \mathrm{~b}}$ & $\underline{\mathrm{d}}_{1 \mathrm{~b}}+\underline{\mathrm{d}}_{1 \mathrm{~b}^{\prime}}$ & $\underline{\mathrm{d}}_{2 \mathrm{~b}}$ & $\underline{d}_{2 b^{\prime}}$ & $\underline{\mathrm{d}}_{3 \mathrm{~b}}-\mathrm{H}_{2} \mathrm{O}$ & $\underline{\mathrm{e}}_{4 \mathrm{~b}^{\prime}}$ & $\underline{\mathrm{e}}_{3 \mathrm{~b}}$ & $\underline{f}_{1 \mathrm{~b}}$ & $\underline{f}_{3 b}$ & $\underline{f}_{2 \mathrm{~b}}+\underline{\mathrm{f}}_{2 \mathrm{~b}^{\prime}}$ & $\underline{\underline{e}}_{6 b^{\prime}}$ & $\underline{\mathrm{e}}_{6 \mathrm{~b} "}$ \\
\hline 656 & 24:0 & d18:1 & & & 418 & & & & 245 & $289^{d}$ & $271^{d}$ & 259 & & 282 & 258 & & & & & \\
\hline 654 & $24: 1$ & d18:1 & & & 416 & & & & 245 & $289^{d}$ & $271^{d}$ & 259 & & 282 & 258 & & & & & \\
\hline 657 & $24: 1$ & $d_{3}-d 18: 1$ & & & 419 & & & & 245 & $290^{\mathrm{d}}$ & $271^{d}$ & 260 & & 284 & 259 & & & & & \\
\hline 432 & $8: 0$ & d18:1 & 366 & 360 & 194 & & & & 245 & $289^{d}$ & $271^{d}$ & 259 & & 282 & 258 & & & & & \\
\hline 544 & $16: 0$ & d18:1 & 478 & 472 & 306 & & & & 245 & $289^{d}$ & $271^{d}$ & 259 & & 282 & 258 & & & & & \\
\hline 572 & $18: 0$ & d18:1 & 506 & 500 & 334 & & & & 245 & $289^{d}$ & $271^{d}$ & 259 & & 282 & 258 & & & & & \\
\hline 658 & $24: 0$ & d18:0 & 592 & 586 & 418 & & & & $247^{d}$ & $291^{d}$ & $273^{d}$ & 261 & & 284 & & & & & & \\
\hline 661 & $24: 0$ & $d_{3}-d 18: 0$ & 593 & 586 & 419 & & & & $247^{d}$ & $292^{d}$ & $273^{d}$ & 262 & & 286 & & & & & & \\
\hline 574 & $18: 0$ & d18:0 & 508 & 502 & 334 & & & & $247^{d}$ & $291^{d}$ & $273^{d}$ & 261 & & 284 & & & & & & \\
\hline 672 & h24:0 & d18:1 & 606 & & & & & & 245 & 289 & 271 & & & & $258^{d}$ & 334 & 286 & 316 & & \\
\hline 676 & $d_{1}-h 24: 0$ & $\mathrm{~d}_{3}-\mathrm{d} 18: 1$ & 607 & & & & & & 245 & 291 & 271 & & & & $260^{d}$ & 338 & 288 & 318 & & \\
\hline 670 & h24:1 & d18:1 & 604 & & & & & & 245 & 289 & 271 & & & & $258^{d}$ & 334 & 286 & 316 & & \\
\hline 532 & h16:0 & d16:1 & 466 & & & & & & 217 & 261 & 243 & & & & $230^{\mathrm{d}}$ & 306 & 258 & 288 & & \\
\hline 546 & h16:0 & d17:1 & 480 & & & & & & 231 & 275 & 257 & & & & $244^{d}$ & 320 & 272 & 302 & & \\
\hline 560 & h16:0 & d18:1 & 494 & & & & & & 245 & 289 & 271 & & & & $258^{d}$ & 334 & 286 & 316 & & \\
\hline 562 & h16:0 & d18:0 & 496 & & & & & & 247 & 291 & 273 & & & & 260 & 336 & 288 & $318^{d}$ & & \\
\hline 590 & h18:0 & d18:0 & 524 & & & & & & 247 & 291 & 273 & & & & 260 & 336 & 288 & $318^{d}$ & & \\
\hline 548 & h16:0 & d17:0 & 482 & & & & & & 233 & 277 & 259 & & & & 246 & 322 & 274 & $304^{d}$ & & \\
\hline 756 & $\omega 30: 0$ & d18:1 & 690 & & & & & & 245 & 289 & 271 & 259 & & 282 & 258 & & & & & \\
\hline \multirow[t]{2}{*}{784} & $\omega 30: 0$ & $\mathrm{~d} 20: 1$ & 718 & & & & & & 273 & 317 & 299 & 287 & & 310 & 286 & & & & & \\
\hline & $\omega 32: 0$ & d18:1 & 718 & & & & & & 245 & 289 & 271 & 259 & & 282 & 258 & & & & & \\
\hline 578 & h16:0 & $\mathrm{t} 18: 0$ & 512 & & & & & & 263 & 307 & 289 & & $273^{d}$ & & 276 & 352 & 304 & 334 & & \\
\hline 564 & h16:0 & $\mathrm{t} 17: 0$ & 498 & & & & & & 249 & 293 & 275 & & $259^{d}$ & & 262 & 338 & 290 & 320 & & \\
\hline \multirow[t]{2}{*}{800} & $\omega 30: 0$ & $\mathrm{t} 20: 1$ & 734 & & & 574 & 556 & 538 & 289 & 333 & 315 & 303 & & & & & & & 284 & $278^{d}$ \\
\hline & $\omega 32: 0$ & t18:1 & 734 & & & 602 & 584 & 566 & 261 & 305 & 287 & 275 & & & & & & & 256 & $250^{d}$ \\
\hline 772 & $\omega 30: 0$ & $\mathrm{t} 18: 1$ & 706 & & & 574 & 556 & 538 & 261 & 305 & 287 & 275 & & & & & & & 256 & $250^{d}$ \\
\hline 744 & $\omega 28: 0$ & t18:1 & 678 & & & 546 & 528 & 510 & 261 & 305 & 287 & 275 & & & & & & & 256 & $250^{d}$ \\
\hline \multirow[t]{3}{*}{674} & $24: 0$ & $\mathrm{t} 18: 0$ & 608 & & & & & & $263^{d}$ & 307 & $289^{d}$ & & & 282 & & & & & & \\
\hline & 25:0 & $\mathrm{t} 17: 0$ & 608 & & & & & & $249^{d}$ & 293 & $275^{d}$ & & & 268 & & & & & & \\
\hline & 25:0 & $\mathrm{t} 17: 0$ & 608 & & & & & & $235^{d}$ & 279 & $261^{d}$ & & & 254 & & & & & & \\
\hline 660 & $24: 0$ & $\mathrm{t} 17: 0$ & 594 & & & & & & $249^{d}$ & 293 & $275^{d}$ & & & 268 & & & & & & \\
\hline 702 & $26: 0$ & $\mathrm{t} 18: 0$ & 636 & & & & & & $263^{d}$ & 307 & $289^{d}$ & & & 282 & & & & & & \\
\hline 688 & h24:0 & $\mathrm{t} 18: 1$ & 622 & & & & & & 261 & 305 & $287^{d}$ & & $271^{d}$ & & 274 & 350 & 302 & $332^{d}$ & $256^{d}$ & 250 \\
\hline 716 & h26:0 & $\mathrm{t} 18: 1$ & 650 & & & & & & 261 & 305 & $287^{d}$ & & $271^{d}$ & & 274 & 350 & 302 & $332^{d}$ & $256^{d}$ & 250 \\
\hline
\end{tabular}


Therefore, ceramides with a t18:1-LCB can be easily recognized by the presence of $m / z 250,256,280$, and 286 in addition to ions at $m / z 305\left(\underline{\mathrm{d}}_{1 \mathrm{~b}}+\underline{\mathrm{d}}_{1 \mathrm{~b}}\right), 287\left(\underline{\mathrm{d}}_{2 \mathrm{~b}}\right), 304$ $\left(\underline{\mathrm{e}}_{2 \mathrm{~b}}+\underline{\mathrm{e}}_{2 \mathrm{~b}}\right), 275\left(\underline{\mathrm{d}}_{2 \mathrm{~b}}\right)$, and $289\left(\underline{\mathrm{d}}_{3 \mathrm{~b}}\right)$. Figure 6b illustrates the product-ion spectrum of $\mathrm{m} / \mathrm{z} 800$, which contains two sets of the feature ions that identify both a t20:1/ $\omega 30: 0-C e r$ and a t18:1/ $\omega 32: 0-C e r$ isomer.

The subclass of t18:1/hFA-Cer found in human stratum corneum is mainly composed of $\mathrm{t} 18: 1 / \mathrm{h} 24: 0-$ Cer and t18:1/h26:0-Cer [5], which yields the lithiated molecular species at $\mathrm{m} / \mathrm{z} 688$ and 716, respectively, by ESI. Both the $[\mathrm{M}+\mathrm{Li}]^{+}$ions of $\mathrm{t} 18: 1 / \mathrm{h} 24: 0-\mathrm{Cer}$ at $\mathrm{m} / \mathrm{z}$ 688 (Figure 6c) and of the t18:1/h26:0-Cer at $\mathrm{m} / \mathrm{z} 716$ (Figure 6d) undergo vigorous fragmentation when subjected to CAD. This is attributable to the presence of the $\alpha$-hydroxyl group in the fatty acyl substituent of the molecule, as observed earlier. The major ions may arise from the same fragmentation pathways as described in Scheme 2. The fragment ions and the assignment of the ion species observed for the two ceramides after CAD are shown in Tables 1 and 2 . The product-ion spectrum of $\mathrm{t} 18: 1 / \mathrm{h} 24: 0-$ Cer at $\mathrm{m} / \mathrm{z} 688$ (Figure $6 \mathrm{c}$ ) is dominated by a prominent ion at $m / z 322\left(\mathrm{e}_{1 \mathrm{~b}}\right)$, and ions at $m / z 289$ $\left(\underline{\mathrm{d}}_{3 \mathrm{~b}}\right), 304\left(\underline{\mathrm{e}}_{2 \mathrm{~b}}+\underline{\mathrm{e}}_{2 \mathrm{~b}^{\prime}}\right)$, and $286\left(\underline{\mathrm{e}}_{3 \mathrm{~b}^{\prime}}+\underline{\mathrm{e}}_{5 \mathrm{~b}^{\prime}}\right)$ that reflect the 6-hydroxysphing-4-enine LCB. The ions at $m / z 345\left(\underline{c}_{3 \mathrm{a}}\right)$, $416\left(\underline{c}_{2 a}\right)$, and $390\left(\underline{d}_{1 a}\right)$ that reflect the h24:0 fatty acyl substituent are of low abundance. The product-ion spectrum of the $t 18: 1 / \mathrm{h} 26: 0$-Cer at $\mathrm{m} / \mathrm{z} 716$ (Figure $6 \mathrm{~d}$ ) is also dominated by the $m / z 322$ ion along with the above described ions that reflect the t18:1-LCB, whereas the h26:0 fatty acid substituent is revealed by ions at $m / z 373$ $\left(\underline{c}_{3 \mathrm{a}}\right), 444\left(\underline{\mathrm{c}}_{2 \mathrm{a}}\right)$, and $418\left(\underline{\mathrm{d}}_{1 \mathrm{a}}\right)$. The identification of the minor isomeric component in the same spectrum (Figure $6 \mathrm{~d}$ ) again is established by the second set of the diagnostic ions that reflect the t20:1-LCB and h24:0-FA. In contrast, the $[\mathrm{M}+\mathrm{Li}]^{+}$ions of $\mathrm{t} 18: 1 / \omega \mathrm{FA}-\mathrm{Cer}$ (Figure $6 \mathrm{a}$ and $\mathrm{b}$ ) undergo less fragmentation and the fragment ions are dominated by the ions reflecting the fatty acyl substituent.

\section{Conclusions}

Ceramides isolated from living organisms occur as complex mixture of different classes. For example, ceramides in human stratum corneum alone consist of at least eight subclasses [2-6], and even each ceramide class is a complex mixture of individual molecular species, which may consist of more than one isomer, as is revealed by the present method. Previous study by FAB in the structural characterization of ceramides using high-energy tandem mass spectrometry was limited in a small variety of ceramides and isomer differentiation among ceramide classes was not demonstrated [19]. This paper, for the first time as to our knowledge, reports an extensive study including a large variety of structurally diverse ceramides using lowenergy CAD tandem mass spectrometry with ESI. Although the major fragment ions observed are similar to that reported by FAB high-energy CAD, some significant differences from the $\mathrm{FAB}$ method were observed:
(1) The classical $\mathrm{C}-\mathrm{C}$ bond cleavages arising from charge-remote fragmentation process were not present, and (2) ions arising from cleavage of the $\beta-\gamma$ bond of the fatty acid substituent ( $\mathrm{K}$ type ion) and from neutral loss of 240 ( $\mathrm{S}$ type ion) and of 239 ( $\mathrm{S}+1$ type ion) (for sphingosine LCB) are not observable [19]. However, the low-energy CAD tandem mass spectra obtained in this study contain multiple abundant fragment ions that reflect both the fatty acid and the LCB substituents of the molecules and thus, structural identification can be easily achieved. These features of the tandem mass spectra are especially useful for identification of isomeric structures in mixtures. This has been demonstrated in Figures 5 and 6, in which more than one isomer can be found. Other important findings are that the $\underline{a}_{1}, \underline{a}_{2}$, and $\left(\underline{a}_{1}-30\right)$ ions (from consecutive losses of $\mathrm{H}_{2} \mathrm{O}$ and $\mathrm{HCHO}$ ), which are abundant in our study, are not present in the previous study by FAB [19]. These feature ions have been successfully used for screening ceramide in biological samples by tandem mass spectrometry [25].

The methods described here permit the structure of ceramides to be revealed in detail. The fragmentation pathways for the ion formations are similar to those reported for glycosphingolipids [24]. The application of this technique to the structural determination of an entire class of new 6-hydroxy-4-sphingenine containing ceramides in human skin is now in progress.

\section{Acknowledgments}

This research was supported by U.S. Public Health Service grants P41-RR-00954, R37-DK-34388, P60-DK-20579, and P01-HL-57-278 and grant 996003 from the Juvenile Diabetes Foundation.

\section{References}

1. Wertz, P. W.; Downing, D. T. Ceramides of Pig Epidermis: Structure Determination. J. Lipid Res. 1983, 24, 759-765.

2. Wertz, P. W.; Downing, D. T. Covalently Bound Hydroxyacylsphingosine in the Stratum Corneum. Biochim. Biophys. Acta. 1987, 917, 108-111.

3. Wertz, P. W.; Swartzendruber, D. C.; Madison, K. C.; Downing, D. T. Composition and Morphology of Epidermal Cyst Lipids. J. Invest. Dermatol. 1987, 89, 419-425.

4. Wertz, P. W.; Madison, K. C.; Downing, D. T. Covalently Bound Lipids of Human Stratum Corneum. J. Invest. Dermatol. 1989, 92, 109-111.

5. Robson, K. J.; Stewart, M. E.; Michelsen, S.; Lazo, N. D.; Downing, D. T. 6-Hydroxy-4-Sphingenine in Human Epidermal Ceramides. J. Lipid Res. 1994, 35, 2060-2068.

6. Stewart, M. E.; Downing, D. T. A New 6-Hydroxy-4-Sphingenine-Containing Ceramide in Human Skin. J. Lipid Res. 1999, 40, 1434-1439.

7. Hannun, Y. A.; Luberto, C. Ceramide in the Eukaryotic Stress Response. Trends Cell Biol. 2000, 10, 73-80.

8. Kolesnick, R. N.; Kronke, M. Regulation of Ceramide Production and Apoptosis. Ann. Rev. Physiol. 1998, 60, 643-665.

9. Okazaki, T.; Kondo, T.; Tashima, M. Diversity and Complexity of Ceramide Signaling in Apoptosis. Cell Signal. 1998, 10, 685-692.

10. Obeid, L. M.; Hannun, Y. A. Ceramide: A Stress Signal and Mediator of Growth Suppression and Apoptosis. J. Cell Biochem. 1995, 58, 191-198. 
11. Fishbein, J. D.; Dobrowsky, R. T.; Bielawska, A.; Garrett, S.; Hannun, Y. A. Ceramide-Mediated Growth Inhibition and CAPP are Conserved in Saccharomyces cerevisiae. J. Biol. Chem. 1993, 268, 9255-9261.

12. Venable, M. E.; Lee, Y. L.; Smith, M. J.; Bielawska, A; Obeid, L. M. Role of Ceramide in Cellular Senescence. J. Biol. Chem. $1995,67,27-38$.

13. Chao, M. V. Ceramide: A Potential Second Messenger in the Nervous System. Mol. Cell Neurosci. 1995, 6((2)), 91-96.

14. Cremesti, A. E.; Fischl, A. S. Current Methods for the Identification and Quantitation of Ceramides: An Overview. Lipids 2000, 35, 937-945 and references therein.

15. Sullards, M. C.; Merrill, A. H., Jr. Analysis of Sphingosine 1-Phosphate, Ceramides, and Other Bioactive Sphingolipids by High-Performance Liquid Chromatography-Tandem Mass Spectrometry. Science's STKE 2001, 1-11 and references therein.

16. Liebisch, G.; Drobnik, W.; Reil, M.; Trumbach, B.; Arnecke, R.; Olgemoller, B.; Roscher, A.; Schmitz, G. Quantitative Measurement of Different Ceramide Species from Crude Cellular Extracts by Electrospray Ionization Tandem Mass Spectrometry (ESI-MS/MS). J. Lipid Res. 1999, 40, 1539-1546.

17. Gu, M.; Kerwin, J. L.; Watts, J. D.; Aebersold, R. Ceramide Profiling of Complex Lipid Mixtures by Electrospray Ionization Mass Spectrometry. Anal. Biochem. 1997, 244, 347-356.

18. Ann, Q.; Adams, J. Structural Determination of Ceramides and Neutral Glycosphingolipids by Collisional Activation of [M + $\mathrm{Li}^{+}$ions. J. Am. Soc. Mass Spectrom. 1992, 3, 260-263.
19. Ann, Q.; Adams, J. Structural-Specific Collison-Induced Fragmentations of Ceramides Cationized with Alkaline-Metal Ions. Anal. Chem. 1993, 65, 7-13.

20. Costello, C. E., Vath, J. E. In Methods in Enzymology; McCloskey, J. A., Ed.; Academic Press: San Diego, CA, 1990; Vol CXCIII, pp 738-768.

21. Hsu, F.-F.; Turk, J. Structural Determination of Sphingomylin by Tandem Mass Spectrometry with Electrospray Ionization. J. Am. Soc. Mass Spectrom. 2000, 11, 437-449.

22. Adams, J.; Gross, M. L. Energy Requirements for Remote Charge Site Decompositions and Structural Information from Collisional Activation of Alkali Metal Cationized Fatty Alcohols. J. Am. Chem. Soc. 1988, 108, 6915-6921.

23. Hsu, F.-F., Turk, J. Characterization of Ceramides by Low Energy Collisional-Activated Dissociation Tandem Mass Spectrometry with Negative-Ion Electrospray Ionization. J. Am. Soc. Mass Spectrom. 2002, 13, 558-570.

24. Hsu, F.-F.; Turk, J. Structural determination of Glycosphigolipids as Lithiated Adducts by Electrospray Ionization Mass Spectrometry Using Low-Energy Collisional-Activated Dissociation on a Triple Stage Quadrupole Instrument. J. Am. Soc. Mass Spectrom. 2001, 12, 61-79.

25. Hsu, F.-F., Turk, J., Stewart, M. E., Downing, D. T. Total Analysis of New 6-Hydroxy-4-Sphingenine-Containing Ceramides in Human Skin by ESI Tandem Mass Spectrometry, unpublished. 